\title{
Assessment of Government Intervention Effectiveness in Scrubbing COVID-19 Pandemic and Its Pros and Cons on Educational Activities, the Case of Dire Dawa City
}

\author{
Gizaw Tesfaye Yifru' \\ Bekele Yazie Derso ${ }^{2}$ \\ Alemayehu Zewdie Shibeshi ${ }^{3}$ \\ 'College of Natural and Computational \\ Sciences, Dire Dawa University, Dire \\ Dawa, Ethiopia; ${ }^{2}$ College of Medicine and \\ Health Sciences, Dire Dawa University, \\ Dire Dawa, Ethiopia; ${ }^{3}$ College of Social \\ Science and Humanities, Dire Dawa \\ University, Dire Dawa, Ethiopia
}

Background: Coronaviruses are known as a large family of viruses known to cause respiratory infections which are considered as a pandemic by WHO and widely distributed all over the globe; causing several damages to all aspects of human being's life.

Objective: To assess and identify the determinants of government intervention effectiveness in scrubbing COVID-19 and its pros and cons on educational activity in Dire Dawa City.

Methods: Stratified random sampling was hired to draw a sample of teachers from a list of teachers that were taught at both selected private and public educational institutes.

Results: A $57.6 \%$ of educators responded as the government was effective in mitigating the pandemic. Out of 250 educators, $9.6 \%, 10.8 \%, 8.4 \%, 38.4 \%$, and $32.8 \%$ were reported that they have very poor, poor, neutral, good, and very good level of knowledge about COVID19 , respectively. The respondents' perceptions about the pandemic were rated as not very fear inducing, not fear inducing, neutral, fear inducing, and very fear inducing $3.2 \%, 6.4 \%$, $6.8 \%, 55.2 \%$ and $28.4 \%$, respectively. Logistic regression indicates nine predictors were significant: avoiding touching one's body with unwashed hands, disinfecting surfaces, fatigue, getting flu vaccine, individual limitation in cooperating to cease the disease, how to maintain one's mental health during the isolation, and washing for at least 20 seconds, family care, and self-isolation.

Pros: Reading, family care, watching movies and physical exercise were importance brought by the pandemic to the educators.

Cons: Teachers are obligated to stay at home, unemployment, stress, unable to conduct professional activities, cancellation of training, and loss of motivation.

Conclusion: The results implied us eighty-four variables were significantly associated with government intervention effectiveness, and nine predictors were significantly related with the government's intervention effectiveness in halting the pandemic from logistic regression model.

Keywords: government, teachers, interventions, effectiveness, COVID-19 pandemic, schools, physical distancing, stay at home, educational activities, pros and cons, quarantine

\section{Introduction}

Coronaviruses are a large family of viruses known to cause respiratory infections. These can range from the common cold to more serious diseases such as Severe Acute Respiratory Syndrome (SARS) and Middle East Respiratory Syndrome (MERS). ${ }^{1}$
Correspondence: Gizaw Tesfaye Yifru Tel +251912233221

Email gtgizsky@gmail.com 
This new coronavirus originated in Hubei Province, China and the disease caused by the virus is named COVID-19. ${ }^{1}$

COVID-19 is most likely to spread from person-toperson through: close contact with a person while they are infectious or in the 24 hours before their symptoms appeared, close contact with a person with a confirmed infection who coughs or sneezes, and touching objects or surfaces contaminated from a cough or sneeze from a person with a confirmed infection, and then touching your mouth or face. ${ }^{1}$

\section{Epidemiological Situation of Novel Corona Virus Pandemic}

Globally, as of 4:38pm CEST, 25 August 2021, there have been $213,050,725$ confirmed cases of COVID-19, including 4,448,352 deaths, reported to $\mathrm{WHO}^{2}$ and as of 22 August 2021, a total of 4,619,976,274 vaccine doses have been administered. $^{2}$

In Africa: 5,539,401 confirmed cases and in Ethiopia, from 3 January 2020 to 4:38pm CEST, 25 August 2021, there have been 297,997 confirmed cases of COVID-19 with 4580 deaths, reported to WHO. ${ }^{2}$

As of 22 August 2021, a total of 2,343,6091 vaccine doses have been administered. ${ }^{2}$ Whereas, in Dire Dawa City, as of August 25, there have been 5374 confirmed cases of COVID-19 and 86 deaths reported. ${ }^{3}$

Coronavirus pandemic is spreading globally as of April, 2020: 2,994,690 total confirmed cases, 207,270 deaths whereas in the USA: 965,933 total number of confirmed cases, and 54,877 total deaths reported; ${ }^{4}$ whereas in Ethiopia 123 cases, 3 deaths were reported ${ }^{5}$ and in Dire Dawa City 9 cases and 0 deaths were reported. $^{3}$

In Addis Ababa and Dire-Dawa City Administrations, multi-sectoral steering committees were established to coordinate COVID-19. ${ }^{6}$ Measures were taken including banning mass gathering and crowded public in transport. Humanitarian impact, established multi-sectoral coordination meetings disrupted.

Local rehabilitation centers have been impacted. Actions taken: volunteers mobilized to create awareness and resource mobilization; market regulation and stabilization measures; provide sanitation and hygiene materials.

\section{The Negative Effects of COVID-I 9 on Health Professionals}

Zhang et $\mathrm{al}^{7}$ reported that their findings provide evidence to enable healthcare organizations to identify staff concerned about job satisfaction, life satisfaction, and turnover intention to enable early actions so that these staffs can remain motivated to fight the prolonged COVID-19 pandemic. Another study done by Zhang et $\mathrm{al}^{8}$ implied that healthcare workers are facing high workloads with resource constraints and risk of virus exposure, and healthcare organizations need to support their healthcare workers to reduce their anxiety. Additionally, the study conducted by Yáñez et $\mathrm{al}^{9}$ showed that Peru's healthcare workers' anxiety and mental distress decreased as the distance from the epicenter increases, corroborating the ripple effect and disconfirming the typhoon eye theory.

Yáñez et $\mathrm{al}^{9}$ have reported that their results can help guide mental health service providers toward vulnerable groups of healthcare workers that are closer to Lima, the COVID19 epicenter in Peru.

Further, Alvarez-Risco et $\mathrm{al}^{10}$ reported that Peru was forced into telemedicine due to the pandemic, and the government is working to improve Internet coverage.

\section{Negative Effects of the Pandemic on Citizens}

According to the study finding done by Alvarez-Risco et $\mathrm{al}^{11}$ showed that multitasking behavior was found to negatively influence self-efficacy of -0.332 , whereas selfefficacy showed a positive influence of 0.325 on academic performance.

Alvarez-Risco et al ${ }^{12}$ reported that the pandemic has changed the world, creating the need for new actions from society, including universities and companies.

A study done by Aleidi et $\mathrm{al}^{13}$ implied that self-medication impacts both negatively and positively the health of people, which has become evident during the COVID-19 pandemic. Aleidi et $\mathrm{al}^{13}$ suggested that a continuous awareness and sensitization about the risks of self-medication are warranted.

Further, a study performed by Alvarez-Risco et $\mathrm{al}^{14}$ signalled that the COVID-19 outbreak has highlighted the need to target infodemics that can be as detrimental as an actual epidemic. 
Furthermore, Yáñez et $\mathrm{al}^{15}$ reported that we must be cautious in Peru, where there is a precarious health system, cases keep increasing in small children, pediatric hospitals are saturated with adult patients, and public policies are not necessarily following the global epidemiological alerts.

\section{Negative Effects of the Outbreak on Firms}

A research done by Yan et al $^{16}$ implied that hospitality industry worldwide is suffering under the COVID-19 pandemic.

On the other hand, the study conducted by AlvarezRisco et $\mathrm{al}^{17}$ showed that the impacts of education development, conceptual development, and country supports on the entrepreneur's ability to carry out green entrepreneurship were positive.

Eventually, the Ethiopian government intervenes to take several actions in order to scrub the outbreak of COVID19. But, the question is, are these all government interventions effective or not?

Thus, the effectiveness of these interventions can be measured via indicator variables. Alternatively, if the interventions taken by the government were effective, they have to meet the pre-specified goals: reduce spread of the disease, reduce death, increase recovery rate, increase the probability of finding the person who has been close contact with patient via tracing task force, increased awareness of both rural and urban society, acceptance and practical implementations of stay at home policy, physical distancing, no handshake, frequent hand wash with soap and water, helping the poor, and others.

The happening of multi-dimensionality impact of COVID-19 outbreak worldwide is obvious that our investigation was intended to identify government interventions effectiveness to scrubbing COVID-19 in Dire Dawa City and to find out determinants of government intervention effectiveness, as well as the specific impact of the disease on educational sector in the city, was studied.

\section{Significance of the Study}

The primary importance of the study was to provide information for government and policymakers. Secondly, it is worthy for Dire Dawa City as means of finding out the advantage and the disadvantage of the pandemic on its educational activities and it can be used as remedial action to alleviate from these challenges and it may also use to reduce the possible damage that might face the city in the future due to this wide spreading disaster. Finally, it can be used to identify the determinants of government intervention effectiveness in fighting the disease in the city. Further, it can be used as an input for the study that would be conducted in the area.

\section{Materials and Methods Study Area and Period}

Dire Dawa City was our study area, found 515 K.M. far away to the East of Ethiopia's capital city. The survey was conducted in the time interval of May 01, and June 01, 2020 .

\section{Study Design and Population}

A cross-sectional study design held used to generate quantitative data. The parent population of the study is all teachers (936) who are being teaching in Dire Dawa City selected private and public educational institutions in the year 2020 .

Inclusion criteria: all teachers who teach in the selected schools and that are permanently residing in the city and those were on duty considered.

Exclusion criteria: teachers who teach in rural and who did no found on duty omitted.

\section{Sample Size and Sampling Technique}

To calculate the sample size, level of significance $\alpha=0.05$, allowable margin of error $(\mathrm{d}=0.04)$, and $\mathrm{P}=50 \%, \mathrm{Q}=50 \%$ was employed. The sample was determined to be 366 . Stratified random sampling technique was used. Thus, the study population was categorized into three broad strata on the bases of school type as stratification factor: primary schools, secondary schools and tertiary-level institutes. In order to determine the sample size of each stratum, proportional allocation technique was employed, then the simple random sample of study participants was drawn from each stratum.

\section{Data Collection, Instruments and Procedures}

To generate the data from the primary sources, interviewers administered structured questionnaire. The questionnaire was adopted from World Health Organization (WHO). Semi-telephone survey was used to collect household data pertaining to knowledge, perception, attitude, and opinion about the pandemic, symptoms of the 
outbreak, prevention methods of COVID-19, variables related to government effectiveness in responding and managing the pandemic, education professionals related and educational institute-related variables.

\section{Data Quality Control}

In order to minimize the errors in data collection, the enumerators were trained regarding the objectives of the investigation and the content of the research tool. Supervisors have monitored the enumerators to validate the collected data. The data quality was guaranteed via statistical software.

\section{Measurement and Definitions}

Generally, we have measured the effectiveness of the government intervention action towards fighting COVID19 as (effective $=1$, not effective $=0$ ). Independent variables include interventions taken by the government of Ethiopia and recommended by the World Health Organization - no handshake, social or physical distancing (applicable, not applicable), and lockdown (appropriate, not appropriate).

\section{Data Processing and Analysis}

SPSS26, R, and R Studio softwares have applied for data validation and data analysis. Proportions and other measures which describe the data and Inferential Statistics employed for data analysis. The results are presented via Tables 1-17 and -figure3.

\section{Ethical Consideration}

Dire Dawa University research ethics review committee approved there were no ethical issues. Additionally, support letter with this was given to Dire Dawa Administration Education and Health Bureaus, and permission from each School's Principals and Administrative organ of the Educational Institutes involved in the study has found. After a detailed explanation of the study objectives, all participants were voluntary to be interviewed about the topic under the consideration; informed oral consent was sought before the interview. This was done due to the pandemic season and the data collection method employed. Secret was kept by excluding names, and confidentiality was guaranteed with a considerable amount of care. The information gained was kept anonymous to all of the interviewees. The study was done as per the Declaration of Helsinki requirements.

\section{Results}

\section{Descriptive Statistics Analysis Result}

The primary aim of the study was dealt with government's effectiveness in scrubbing the spread of COVID-19 pandemic in Dire Dawa City. Accordingly, out of 366 total teachers 250 of them were participated in the study and $57.6 \%$ of them responded as the government was effective in ceasing the pandemic.

To start with School types of study respondents, $38.0 \%$ of them were reported as they are teaching in Primary Schools, $31.6 \%$ of them teach in Secondary Schools, and $30.4 \%$ of them teach in Technical colleges and Universities. Out of 250 educators, $9.6 \%, 10.8 \%, 8.4 \%$, $38.4 \%$, and $32.8 \%$ were reported that they have very poor, poor, neutral, good, and very good level of knowledge about COVID-19, respectively.

The respondents' perception about the pandemic were rated as: not very fear inducing, not fear inducing, neutral, fear inducing, and very fear inducing 3.2\%, 6.4\%, 6.8\%, $55.2 \%$ and $28.4 \%$ about pandemic, respectively.

\section{Bivariate Analysis Result}

This section reports the association between the effectiveness of government intervention measures taken to cease the pandemic each of the predictor variables that was significant.

The proportions of educators who rate their level of knowledge about the pandemic to fall in the categories of very poor, poor, neutral, good, and very good were $83.3 \%$, $55.6 \%, 52.4 \%, 43.8 \%$, and $68.3 \%$, respectively, were responded as the government intervention measure was effective in halting the pandemic.

This implies that the proportion of survey respondents' rate of government intervention effectiveness decreases as their level of knowledge about the pandemic increases from poor to good and increases for every good level of respondents' knowledge about the outbreak (see Table 1).

Similarly, the proportion of government effectiveness increases with respondents' knowledge of the symptom of the outbreak. Only $30.0 \%$ of study participants were responded as Fever is not among the symptoms of COVID-19 pandemic and rate the government intervention measures taken to scrub the pandemic was effective as compared to $55.8 \%$ of who did say that it's among the symptoms of the pandemic and rated that the intervention was effective (see Table 2). 


\begin{tabular}{|c|c|c|c|c|c|c|c|}
\hline \multicolumn{3}{|l|}{ 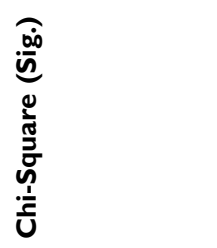 } & \multirow{2}{*}{ 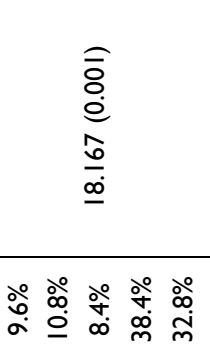 } & \multirow{2}{*}{ 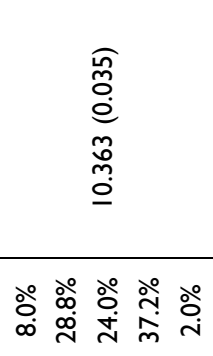 } & \multirow{2}{*}{ 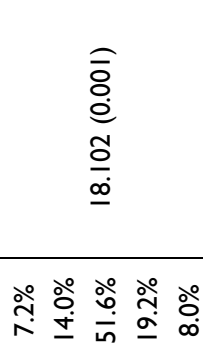 } & \multirow{2}{*}{ 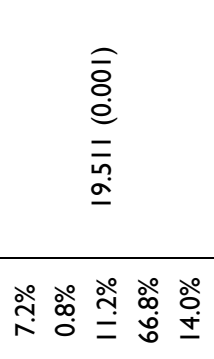 } & \multirow{2}{*}{ 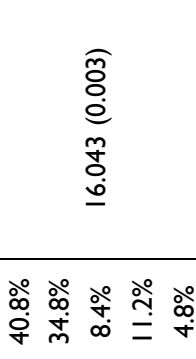 } \\
\hline \multirow{6}{*}{ 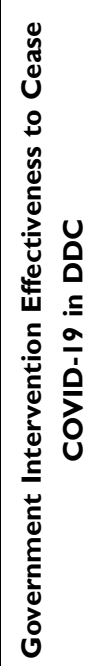 } & \multirow{2}{*}{ 今ึ } & ๖ & & & & & \\
\hline & & $\begin{array}{l}\stackrel{\vec{J}}{J} \\
\text { Ů }\end{array}$ & 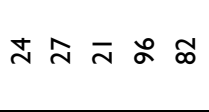 & ำ & 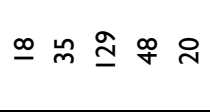 & $\underline{\infty} \sim \stackrel{\infty}{\hat{\sigma}} \stackrel{\llcorner}{m}$ & $\underline{\delta} \bar{\infty} \bar{\sim} \stackrel{\sim}{\sim} \simeq$ \\
\hline & \multirow{2}{*}{ 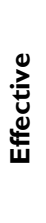 } & ○ & 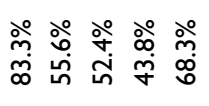 & 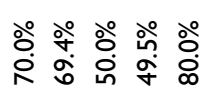 & 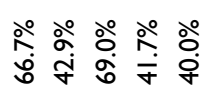 & 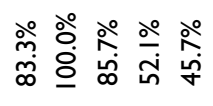 & 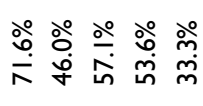 \\
\hline & & 节 & 오느 $=$ f & \pm 유 임 & $\simeq \underline{-}$ 요 $\infty$ & 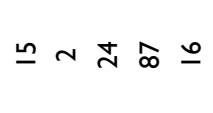 & $\Re g \simeq \underline{ }$ \\
\hline & \multirow{2}{*}{ 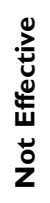 } & ๖ & 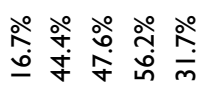 & 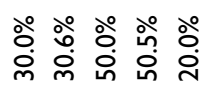 & 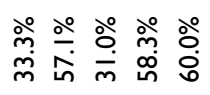 & 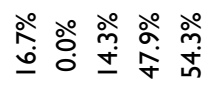 & 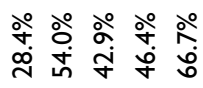 \\
\hline & & ثِّ & $+\simeq 0$ 芩 & $\circ$ 잉 - & • ㅇ \& $\stackrel{\infty}{\sim} \simeq$ & $m \circ+\infty a$ & ते f $\sigma \underline{m}$ \\
\hline \multicolumn{3}{|l|}{ 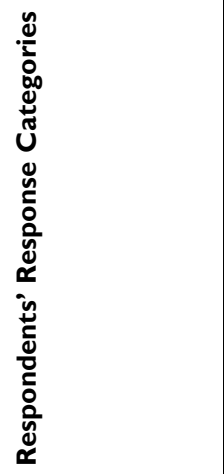 } & 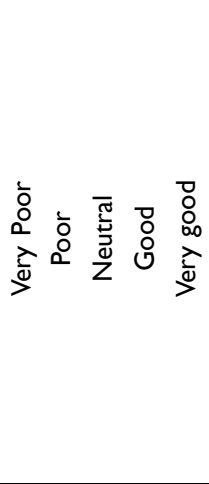 & 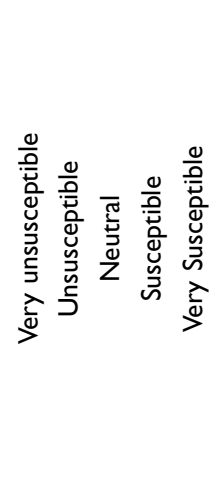 & 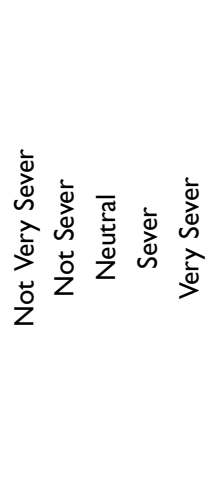 & 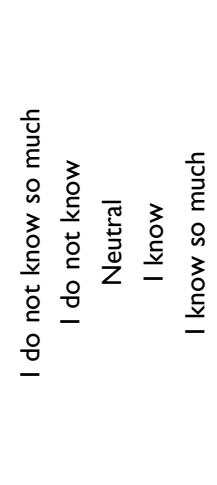 & 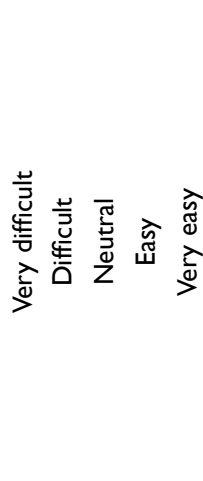 \\
\hline 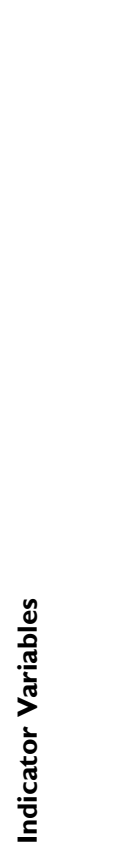 & & & 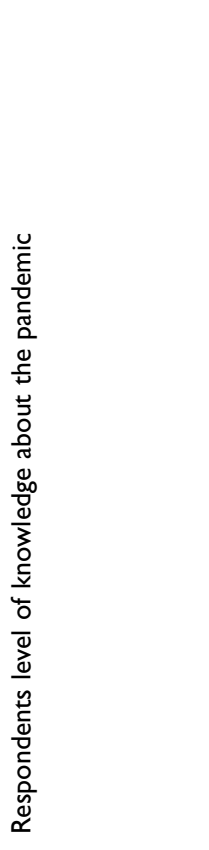 & 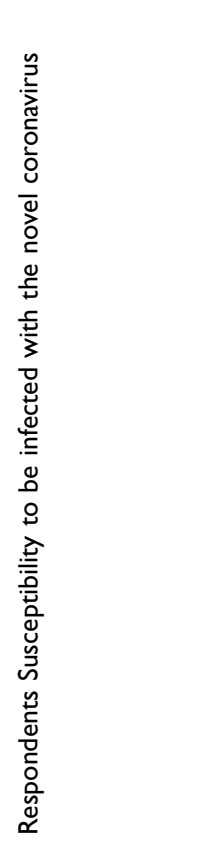 & 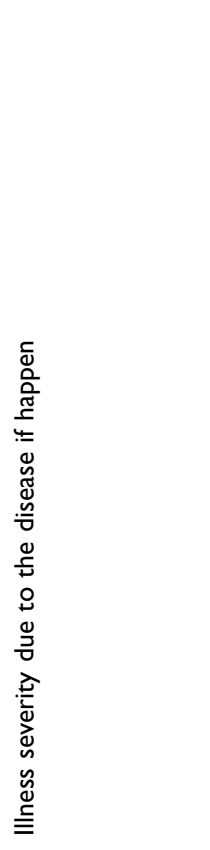 & 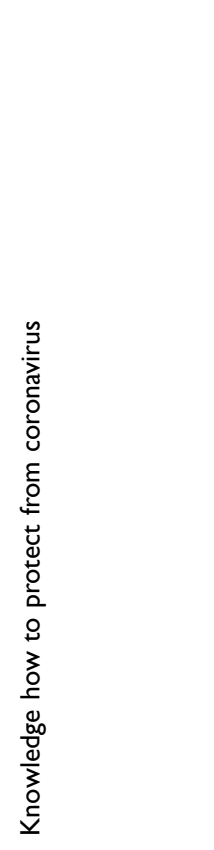 & 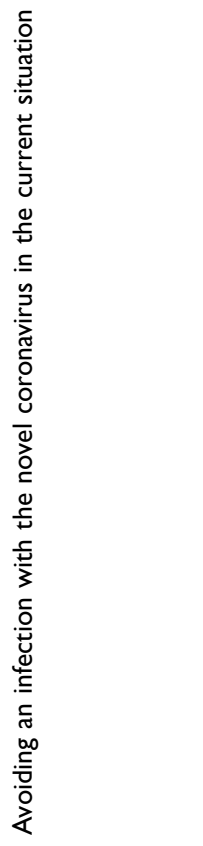 \\
\hline
\end{tabular}




\begin{tabular}{|c|c|c|c|c|c|c|c|}
\hline \multicolumn{3}{|l|}{ 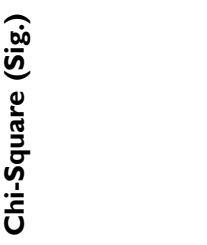 } & 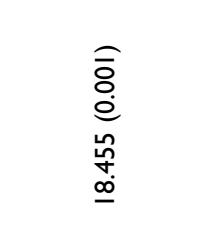 & 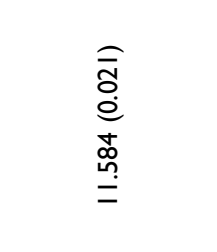 & $\begin{array}{l}\widehat{\mathcal{y}} \\
\stackrel{0}{0} \\
\stackrel{0}{0} \\
\hat{o} \\
\alpha\end{array}$ & 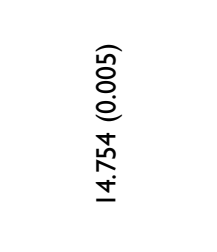 & 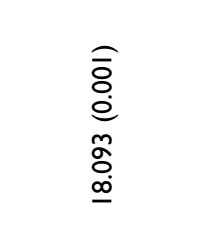 \\
\hline \multirow{6}{*}{ 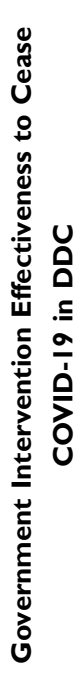 } & \multirow{2}{*}{ ثึ } & ๙ீ & 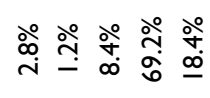 & 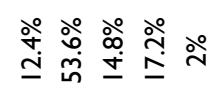 & 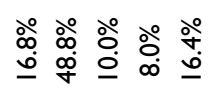 & 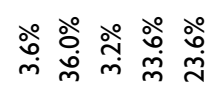 & 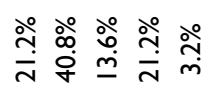 \\
\hline & & 䓂 & $\wedge m \bar{N} \mathscr{I}$ & $\bar{m} \stackrel{\varpi}{m} \hat{m} \tilde{q}$ & 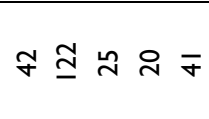 & $\sigma \circ \infty$ ळ & 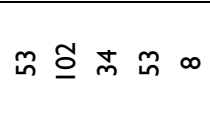 \\
\hline & \multirow{2}{*}{ 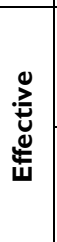 } & ஃ゚ & 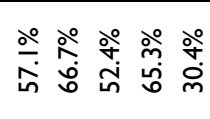 & 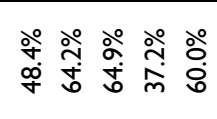 & 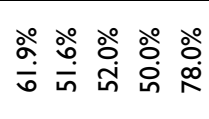 & 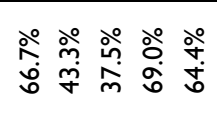 & 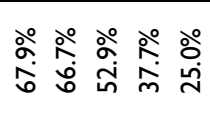 \\
\hline & & 䓂 & $+\sim=\stackrel{m}{=}$ & $\underline{-} \infty \underset{\sim}{-} m$ & 요요응 & 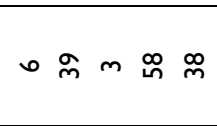 & 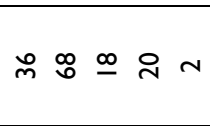 \\
\hline & \multirow{2}{*}{ 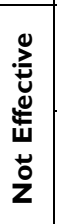 } & ஃீ & 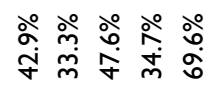 & 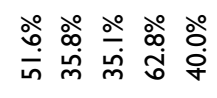 & 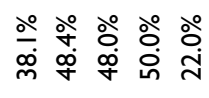 & 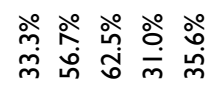 & 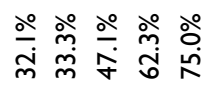 \\
\hline & & 䓂 & $m-$ 으요 & $\underline{\bullet} \stackrel{\infty}{\square} \underline{\sim} \sim$ & $\underline{0}$ 응ㅇㅇ & 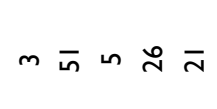 & $\simeq \stackrel{ \pm}{m} \simeq \stackrel{m}{m}$ \\
\hline \multicolumn{3}{|l|}{ 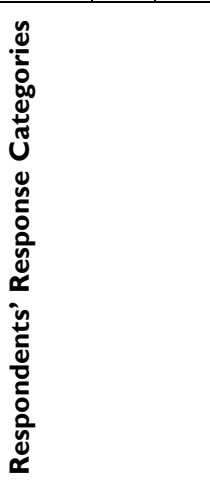 } & 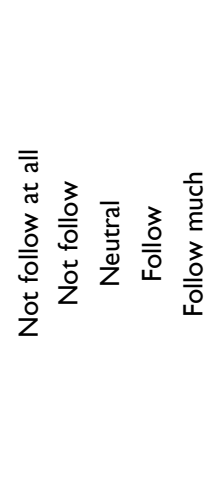 & 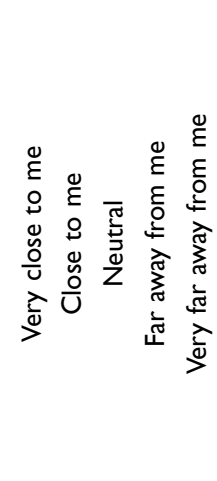 & 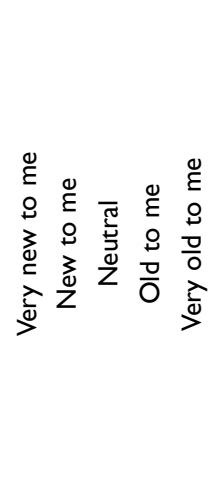 & 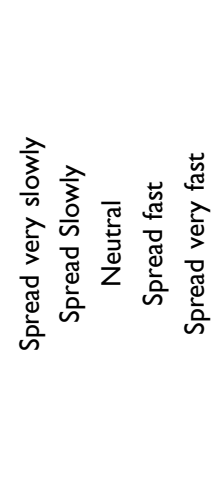 & 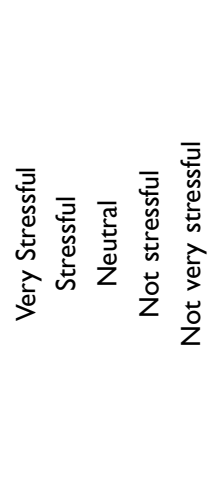 \\
\hline \multicolumn{3}{|l|}{ 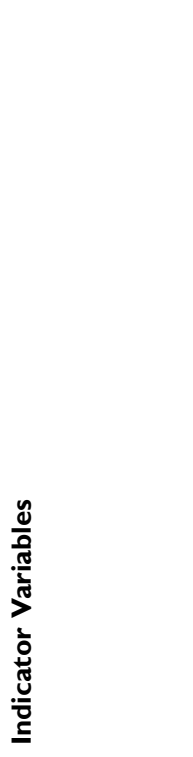 } & 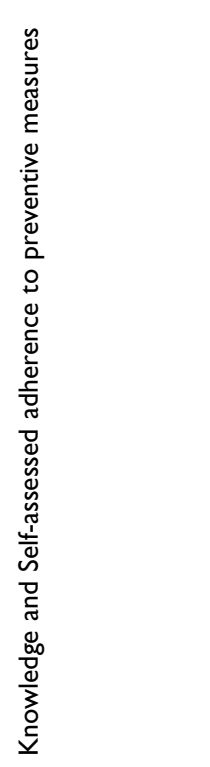 & 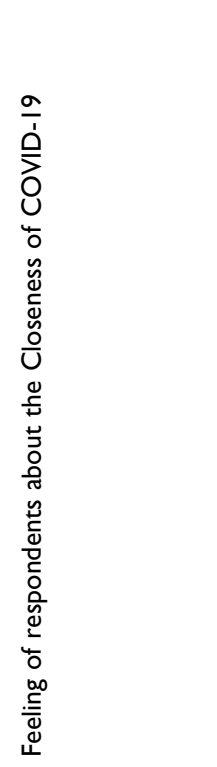 & 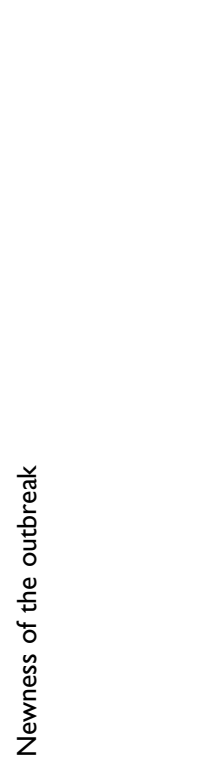 & 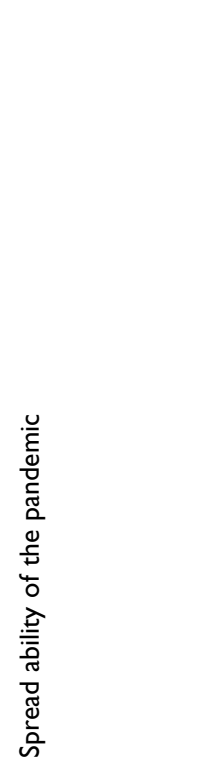 & 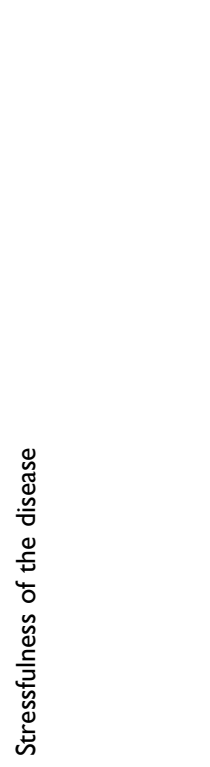 \\
\hline
\end{tabular}




\begin{tabular}{|c|c|c|c|c|c|c|c|c|c|}
\hline \multicolumn{3}{|l|}{ 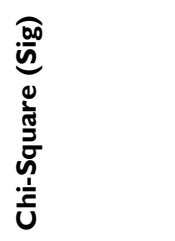 } & $\begin{array}{l}\widehat{\bar{\delta}} \\
\stackrel{0}{0} \\
\underline{m} \\
\underline{\underline{\alpha}}\end{array}$ & 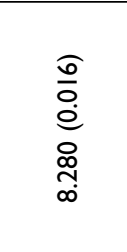 & 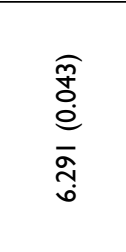 & $\begin{array}{l}\stackrel{\widehat{్}}{0} \\
\stackrel{0}{0} \\
\stackrel{0}{\circ} \\
\frac{m}{n}\end{array}$ & $\begin{array}{l}\widehat{\widehat{o}} \\
\stackrel{0}{0} \\
\infty \\
\tilde{o} \\
\stackrel{\Xi}{=}\end{array}$ & $\begin{array}{l}\widehat{Q} \\
\stackrel{0}{0} \\
\bar{n} \\
\stackrel{0}{0}\end{array}$ & 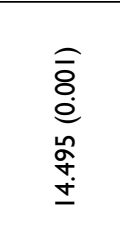 \\
\hline \multirow{6}{*}{ 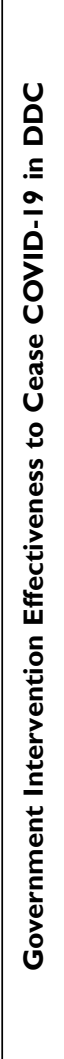 } & \multirow{2}{*}{ ڤึ } & ๙ீ & 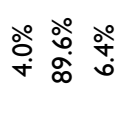 & 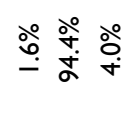 & 守 & 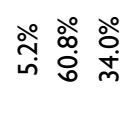 & 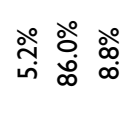 & 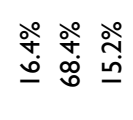 & 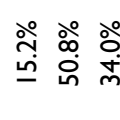 \\
\hline & & 䓂 & 으 헌 & $+\stackrel{\sim}{\sim}$ 으 & 윰 아 & $\underline{\underline{n}} \underline{\underline{n}}$ & $\underline{m} \frac{n}{N} \approx$ & $\bar{\sigma} \Sigma \stackrel{\infty}{m}$ & 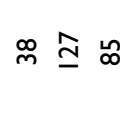 \\
\hline & \multirow{2}{*}{ 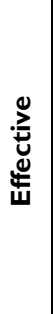 } & ஃீ & 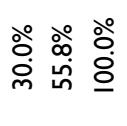 & 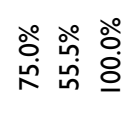 & 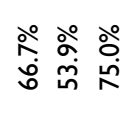 & 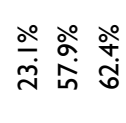 & 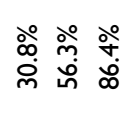 & 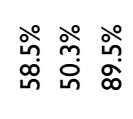 & 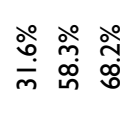 \\
\hline & & 䓂 & $m \stackrel{\llcorner}{\underline{0}} \underline{0}$ & $m \overline{\underline{m}}$ 음 & + 으 이 & $m \stackrel{n}{m}$ & $+\bar{\simeq} a$ & 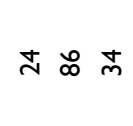 & $\simeq \forall \stackrel{\infty}{\sim}$ \\
\hline & $\sum_{i=t}^{0}$ & ๖ீ & 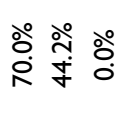 & 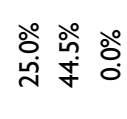 & 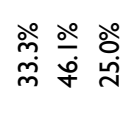 & 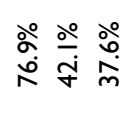 & 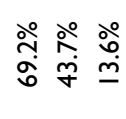 & 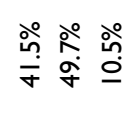 & 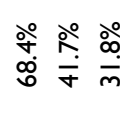 \\
\hline & zo & 䓂 & $\wedge \sigma 0$ & $-\stackrel{\text { Oㅇ }}{0}$ & $\sim$ ㅎㅇ & 의 $\tilde{\sigma}$ & $\sigma \pm m$ & $=\stackrel{\infty}{\infty}+$ & $\stackrel{\sim}{n} \tilde{\sim} \tilde{N}$ \\
\hline 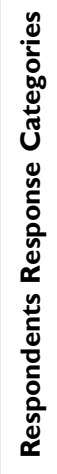 & & & 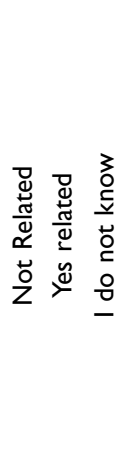 & 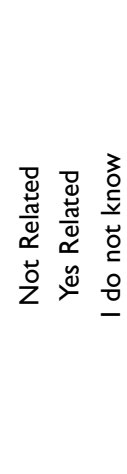 & 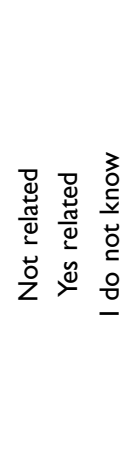 & 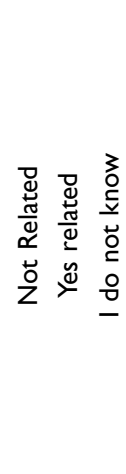 & 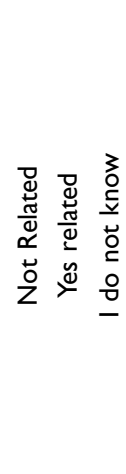 & 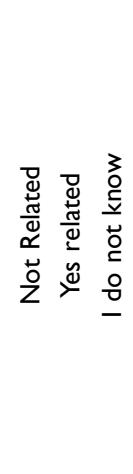 & 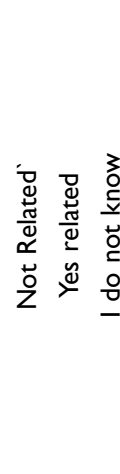 \\
\hline 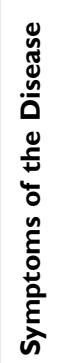 & & & ऐ্ّ & 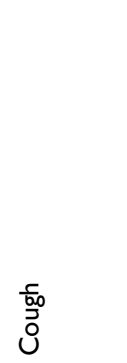 & 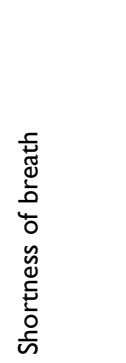 & 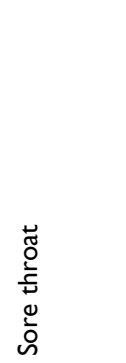 & 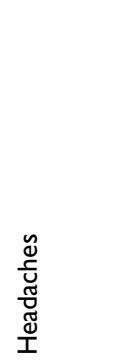 & 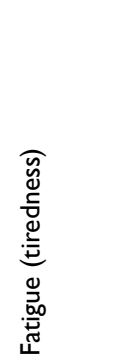 & 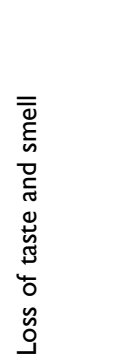 \\
\hline
\end{tabular}


Table 3 Test of Association Between Prevention Measures Practice Taken by the Respondents to Prevent Infection from the Novel Coronavirus and Government Intervention Effectiveness in Dire Dawa City in the Year 2020

\begin{tabular}{|c|c|c|c|c|c|c|c|c|}
\hline \multirow{3}{*}{$\begin{array}{l}\text { Preventive Measures Taken by the } \\
\text { Respondent to Prevent Infection from the } \\
\text { Disease }\end{array}$} & \multirow[t]{3}{*}{$\begin{array}{l}\text { Response } \\
\text { Categories }\end{array}$} & \multicolumn{6}{|c|}{$\begin{array}{c}\text { Government Intervention Effectiveness to } \\
\text { Cease COVID-19 in DDC }\end{array}$} & \multirow[t]{3}{*}{ Chi-Square (Sig) } \\
\hline & & \multicolumn{2}{|c|}{ Not Effective } & \multicolumn{2}{|c|}{ Effective } & \multicolumn{2}{|c|}{ Total } & \\
\hline & & Count & $\%$ & Count & $\%$ & Count & $\%$ & \\
\hline \multirow[t]{2}{*}{ Hand washing for at least 20 seconds } & No I do not & 27 & $77.1 \%$ & 8 & $22.9 \%$ & 35 & $14.0 \%$ & \multirow{2}{*}{$20.115(0.000)$} \\
\hline & Yes I do & 79 & $36.7 \%$ & 136 & $63.3 \%$ & 215 & $86.0 \%$ & \\
\hline \multirow{2}{*}{$\begin{array}{l}\text { Avoiding touching ones' body with unwashed } \\
\text { hands }\end{array}$} & No I do not & 6 & $14.0 \%$ & 37 & $86.0 \%$ & 43 & $17.2 \%$ & \multirow{2}{*}{$17.207(0.000)$} \\
\hline & Yes I do & 100 & $48.3 \%$ & 107 & $51.7 \%$ & 207 & $82.8 \%$ & \\
\hline \multirow[t]{2}{*}{ Use of disinfectant/Sanitizers to clean hands } & No I do not & 27 & $33.8 \%$ & 53 & $66.2 \%$ & 80 & $32.0 \%$ & \multirow{2}{*}{$3.604(0.05)$} \\
\hline & Yes I do & 79 & $46.5 \%$ & 91 & $53.5 \%$ & 170 & $68.0 \%$ & \\
\hline \multirow{2}{*}{$\begin{array}{l}\text { Physical distancing (keeping minimum } 2 \text { meters or } \\
6 \text { feet) }\end{array}$} & No I do not & 16 & $61.5 \%$ & 10 & $38.5 \%$ & 26 & $10.4 \%$ & \multirow{2}{*}{$4.352(0.037)$} \\
\hline & Yes I do & 90 & $40.2 \%$ & 134 & $59.8 \%$ & 224 & $89.6 \%$ & \\
\hline \multirow[t]{2}{*}{ Disinfecting surfaces } & No I do not & 43 & $64.2 \%$ & 24 & $35.8 \%$ & 67 & $26.8 \%$ & \multirow{2}{*}{ I7.777 (0.000) } \\
\hline & Yes I do & 63 & $34.4 \%$ & 120 & $65.6 \%$ & 183 & $73.2 \%$ & \\
\hline
\end{tabular}

Additionally, the proportions of educators who rate the government intervention as effective corresponding cough as a symptom of the disease categories of not related and yes related were $75 \%$ and $55.5 \%$, respectively. This signals that the proportions of respondent rate of government intervention effectiveness in scrubbing the disease less for who responded as yes it's among the symptoms of the pandemic than those who did not respond as it's among the symptoms of novel coronavirus (see Table 2).

Generally, eighty-four indicator variables were significantly associated with the government intervention effectiveness to cease COVID-19 (see Tables 1-12 respectively).

\section{Multiple Logistic Regressions Analysis}

By using multiple logistic regression (Forward Stepwise method), nine predictor variables were found to be significant: Not touching ones, organ with unwashed hands, disinfecting surfaces, fatigue (tiredness), getting the flu vaccine, an individual limitation in cooperating to cease the disease, how to maintain one's mental health during the isolation, hand washing practice for at least 20 seconds, family care practice of educators during the lockdown, and Self-isolation. Before going to the interpretation of the results, various tests were conducted to assess whether the specified model is well fitted to the observed data or not well fitted.

\section{Assessing Logistic Regression Model}

P-value $<0.001$ (Table 13) shows that the model with predictor variables included has a better fit as compared to the model containing only a constant. This intern implies that the predictor variables were significantly affecting the outcome variable that was considered.

The Cox and Snell R-square indicate that $47.2 \%$ of the variation in the dependent variable is explained by the explanatory variables. Similarly, Nagelkerke's R-Square indicates that the $63.4 \%$ of the variability in the government's intervention measure effectiveness in ceasing the pandemic in Dire Dawa City was explained by the independent variables (see Table 14).

The test statistic has a chi-square value of 12.701 and a significance level of 0.123 . This means that the HosmerLemeshow test statistic is not statistically significant and, therefore, our model is quite a good fit to the data (see Table 15).

Out of the 250 educators included in the model $86.8 \%$ of them were correctly predicted which shows the overall percentage of prediction accuracy. The sensitivity is given by $84.7 \%$ and the specificity is given by $89.6 \%$, which indicate that $84.7 \% \%$ of the educators who did say the government intervention were effective and $89.6 \%$ of those who did not were correctly predicted in their respective categories. 


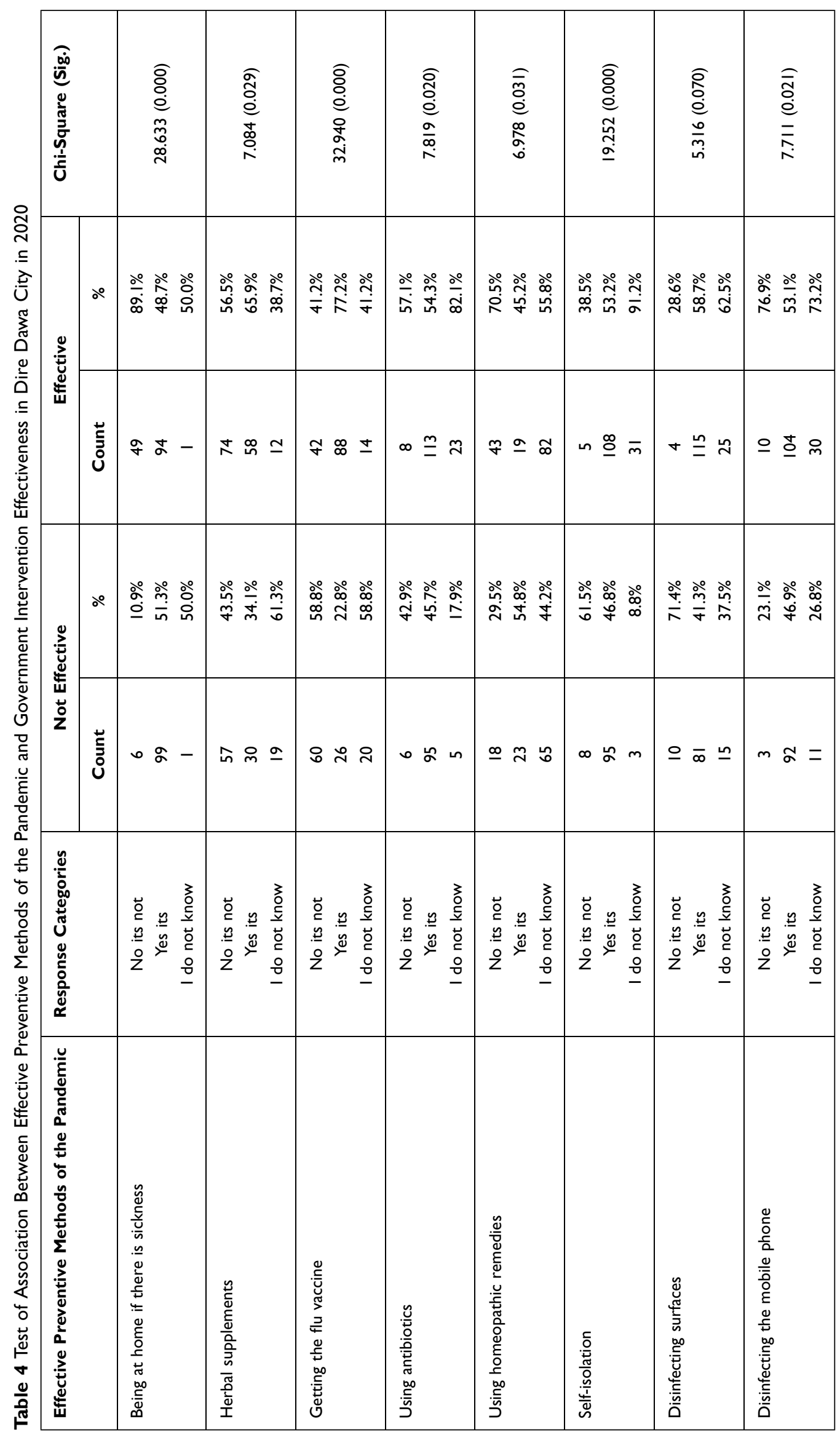




\begin{tabular}{|c|c|c|c|c|c|c|c|c|c|c|c|}
\hline \multicolumn{3}{|l|}{ 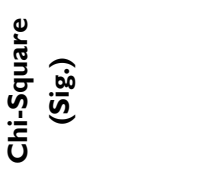 } & 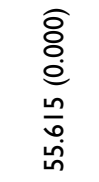 & $\begin{array}{l}\widehat{\bar{\delta}} \\
\dot{e} \\
\underline{n} \\
\underline{\Xi} \\
=\end{array}$ & 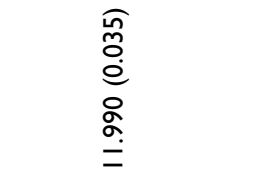 & 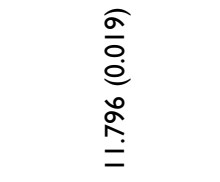 & 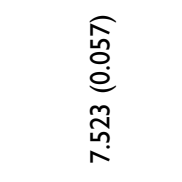 & & 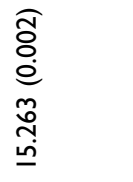 & & 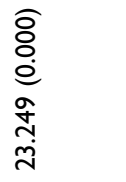 \\
\hline \multirow{6}{*}{ 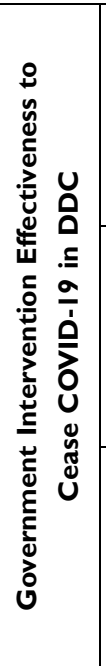 } & \multirow{2}{*}{ હّ̋ } & ஃீ & 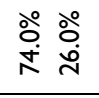 & 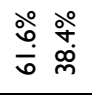 & 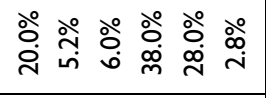 & 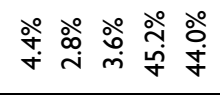 & 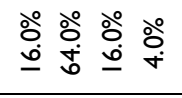 & 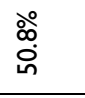 & 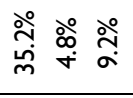 & 产 & 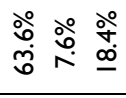 \\
\hline & & $\begin{array}{l}\overrightarrow{5} \\
\stackrel{0}{0}\end{array}$ & $\underline{\infty} \underline{\underline{0}}$ & 艺 。 & 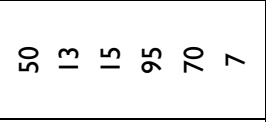 & $=\wedge a \stackrel{m}{=}$ 은 & 우으아응 & $\grave{\cong}$ & $\infty \simeq \tilde{N}$ & $\stackrel{\sim}{\sim}$ & 응 \\
\hline & \multirow{2}{*}{ 总 } & $\circ$ & $\begin{array}{l}\stackrel{\circ}{\circ} \stackrel{\circ}{\circ} \\
\stackrel{\gamma}{\circ}\end{array}$ & $\begin{array}{l}\stackrel{\circ}{\sigma} \stackrel{\circ}{\infty} \\
\stackrel{\alpha}{\alpha}\end{array}$ & 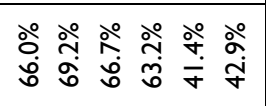 & 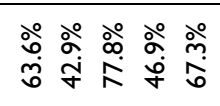 & 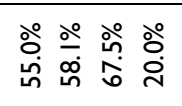 & $\frac{\circ}{\stackrel{\varphi}{n}}$ & 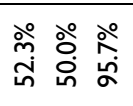 & 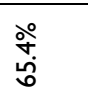 & 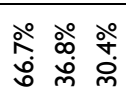 \\
\hline & & $\begin{array}{l}\ddot{\mathbf{z}} \\
\dot{0}\end{array}$ & $\bar{\infty}$ & గ゚ & ma 0 : & $\wedge m \wedge n$ & $\approx a \lesssim N$ & R & \&० & $\simeq$ & $\stackrel{0}{\wedge}$ \\
\hline & \multirow{2}{*}{ 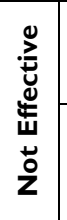 } & $\stackrel{\circ}{\circ}$ & خें ㅇํํ & 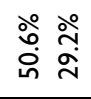 & 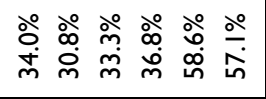 & ○ें. & 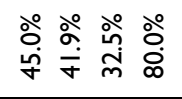 & $\begin{array}{l}\stackrel{\circ}{\circ} \\
\dot{+}\end{array}$ & 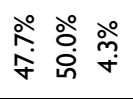 & 号 & 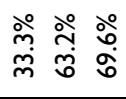 \\
\hline & & $\begin{array}{l}\stackrel{\mathbf{E}}{0} \\
\dot{0}\end{array}$ & $\underline{\underline{D}} n$ & $\stackrel{\infty}{\sim} \stackrel{\infty}{\sim}$ & ニ $\sigma$ in $\operatorname{m}_{\bar{\sigma}} \bar{\sigma}+$ & $+\sigma$ r & $\underline{\infty} \underline{m} \infty$ & in & A $0-$ & $\sigma$ & $\tilde{n} \simeq \tilde{m}$ \\
\hline \multicolumn{2}{|l|}{ 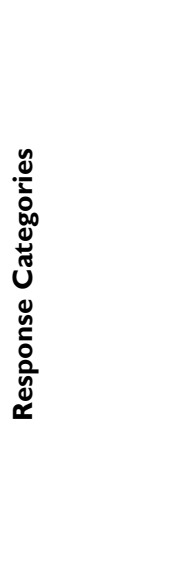 } & & 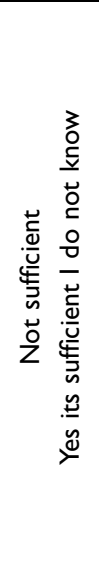 & 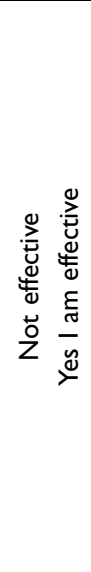 & 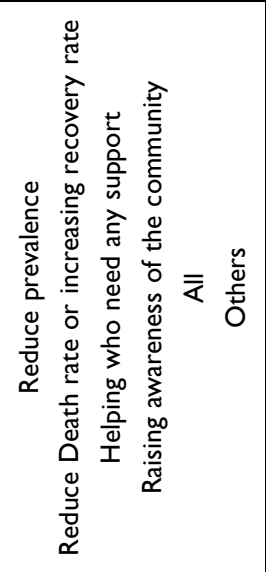 & 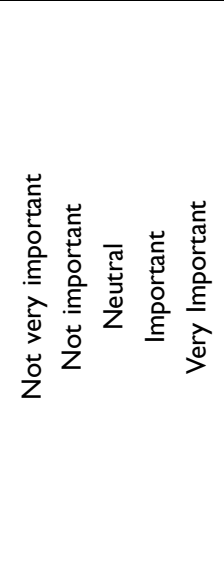 & 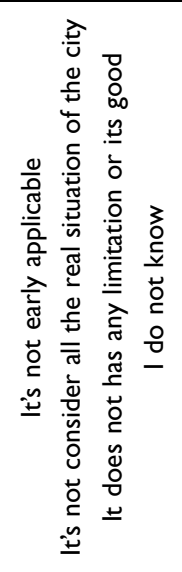 & 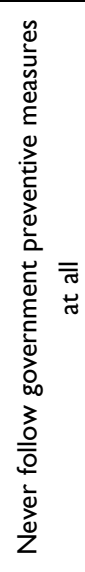 & 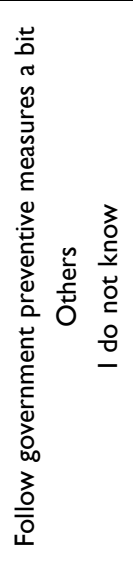 & 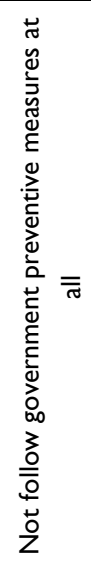 & 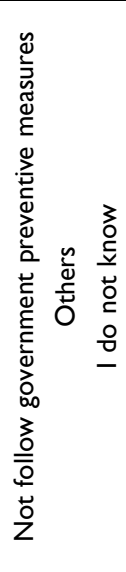 \\
\hline 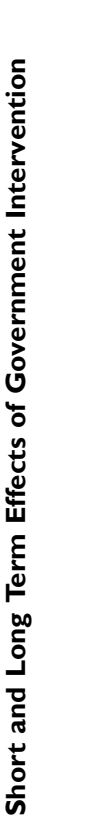 & & & 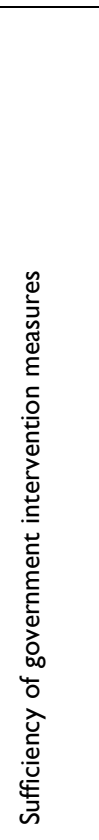 & 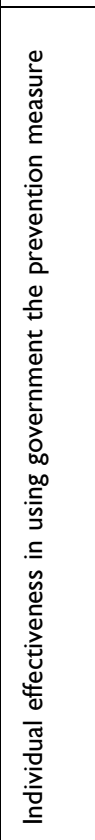 & 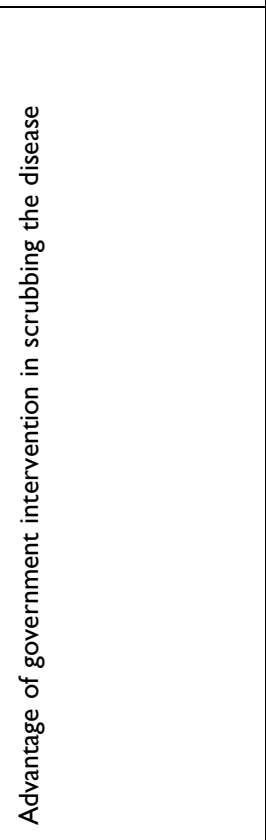 & 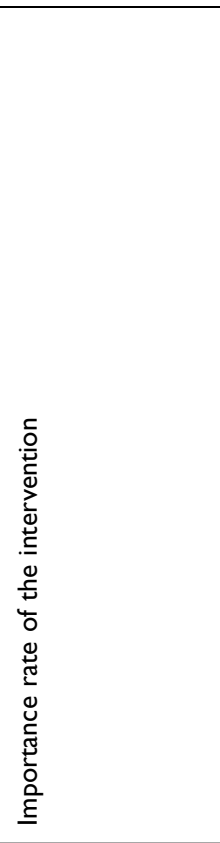 & 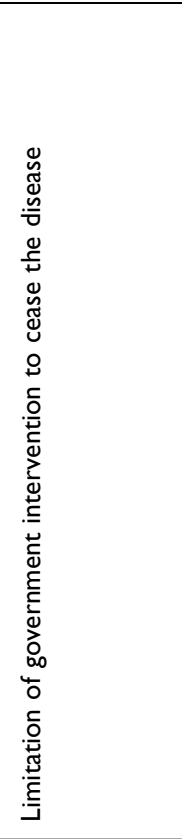 & 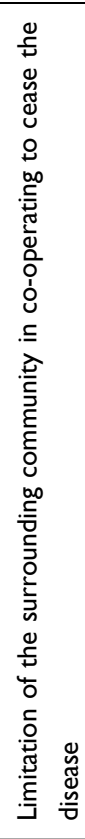 & & 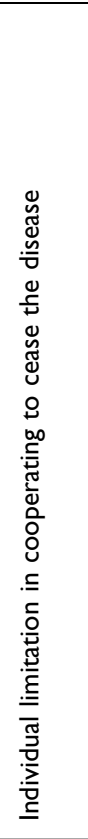 & \\
\hline
\end{tabular}




\begin{tabular}{|c|c|}
\hline 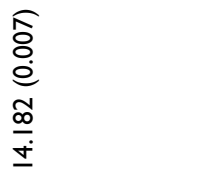 & 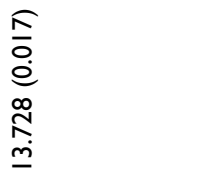 \\
\hline 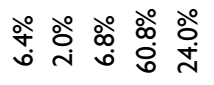 & 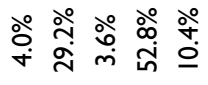 \\
\hline$\underline{ }$ n $\simeq \underline{\underline{ก}}$ 웅 & 으 $\sim a \stackrel{\sim}{\sim}$ ㄴ \\
\hline 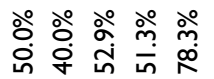 & 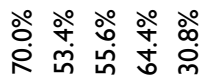 \\
\hline$\infty \sim a \stackrel{\infty}{\sim}$ & $\wedge \stackrel{\sigma}{m}$ in $\stackrel{\infty}{\infty} \infty$ \\
\hline 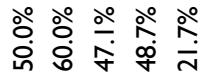 & 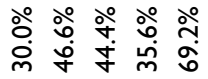 \\
\hline 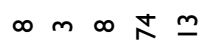 & $m$ 岽 $+\hat{f} \underline{\infty}$ \\
\hline 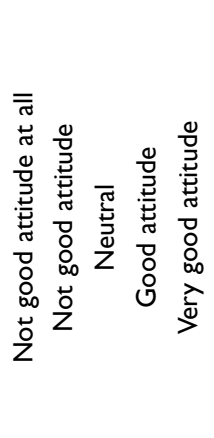 & 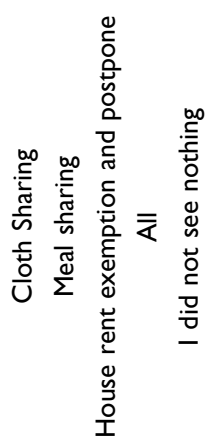 \\
\hline 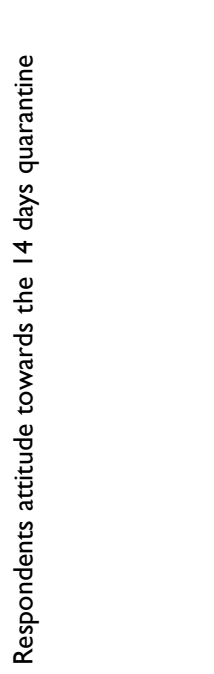 & 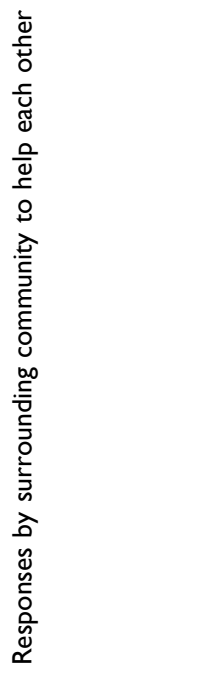 \\
\hline
\end{tabular}

\section{Multiple Logistic Regression Model Analysis Results}

The hypothesis test for individuals (Wald test): $\mathrm{H}_{0}: \beta_{\mathrm{j}}=0$ or $\mathrm{H}_{\mathrm{a}}: \beta_{\mathrm{j}} \neq 0, \mathrm{j}=1,2,3, \ldots, \mathrm{k}$.

As can be seen from Table 17, not touching ones with unwashed hands is significant at the $1 \%$ level. The value of $\exp (\hat{\beta})=11.940$ implies that the odds of government effectiveness are 11.940 times more likely for those respondents who did not refrain from touching one's body with unwashed hands as compared to the survey respondents who did avoid touching their eyes, nose, and mouth with unwashed hands held constant by the other predictors in the model.

For the case of the disinfecting surfaces, the result displayed under Table 17 indicates that it is significant at the $1 \%$ level. The value of $\exp (\hat{\beta})=0.157$ implies that the odds of the government intervention measure were effective in scrubbing the pandemic decrease by a factor of 15.7 for those respondents as they disinfecting a surface. This indicates that survey respondents who were disinfecting surfaces were less likely to rate the government intervention measure was effective in scrubbing the pandemic as compared to those responded as they do not disinfecting a surface.

For the case of the fatigue (tiredness), the result displayed under Table 17 indicates that it is significant at the $1 \%$ level. The value of $\exp (\hat{\beta})=0.069$ implies that the odds of the government intervention measure were effective in scrubbing the pandemic decrease by a factor of 6.9 for those respondents as they were say yes tiredness is the symptom of novel coronavirus pandemic. This indicates that survey respondents who were responded yes tiredness is the symptom of COVID-19 were less likely to rate the government intervention measure was effective in scrubbing the pandemic as compared to those responded as it is not the symptoms of novel coronavirus.

Similarly, the value of $\exp (\hat{\beta})=0.235$ implies that the odds of the government intervention measure were effective in scrubbing the pandemic decrease by a factor of 23.5 for those respondents as they were do not know that fatigue is symptoms for coronavirus pandemic. This indicates that survey respondents who responded as they did not know the fatigue is the symptom of COVID-19 were less likely to rate the government intervention measure was effective in scrubbing the pandemic as compared to those responded as it is not the symptoms of novel coronavirus. 
Table 6 Test of Association Between Government Intervention Effectiveness to Cease the Disease and Its Cons on the Respondents' Educational Activities in Dire Dawa City in the Year 2020

\begin{tabular}{|c|c|c|c|c|c|c|}
\hline \multirow{2}{*}{$\begin{array}{l}\text { Negative Impact of Intervention Methods Held for } \\
\text { Mitigating the Pandemic in the City }\end{array}$} & \multirow{2}{*}{$\begin{array}{l}\text { Response } \\
\text { Categories }\end{array}$} & \multicolumn{2}{|c|}{ Not Effective } & \multicolumn{2}{|c|}{ Effective } & \multirow[t]{2}{*}{ Chi-Square (Sig.) } \\
\hline & & Count & $\%$ & Count & $\%$ & \\
\hline \multirow[t]{3}{*}{ Teachers are obligated to stay at home } & No its not & 29 & $53.7 \%$ & 25 & $46.3 \%$ & \multirow[b]{3}{*}{$9.565(0.008)$} \\
\hline & Yes its & 77 & $41.2 \%$ & 110 & $58.8 \%$ & \\
\hline & I do not know & 0 & $0.0 \%$ & 9 & $100.0 \%$ & \\
\hline \multirow[t]{3}{*}{ Respondents' Fear of unemployment } & No its not & 34 & $34.3 \%$ & 65 & $65.7 \%$ & \multirow[b]{3}{*}{$7.206(0.027)$} \\
\hline & Yes its & 72 & $48.6 \%$ & 76 & $51.4 \%$ & \\
\hline & I do not know & 0 & $0.0 \%$ & 3 & $100.0 \%$ & \\
\hline \multirow[t]{3}{*}{ Stress } & No its not & 41 & $59.4 \%$ & 28 & $40.6 \%$ & \multirow[b]{3}{*}{ II.322 (0.003) } \\
\hline & Yes its & 63 & $36.0 \%$ & 112 & $64.0 \%$ & \\
\hline & I do not know & 2 & $33.3 \%$ & 4 & $66.7 \%$ & \\
\hline \multirow[t]{3}{*}{ Un able to conduct Professional activities } & No its not & 17 & $23.6 \%$ & 55 & $76.4 \%$ & \multirow[b]{3}{*}{$15.987(0.000)$} \\
\hline & Yes its & 87 & $50.9 \%$ & 84 & $49.1 \%$ & \\
\hline & I do not know & 2 & $28.6 \%$ & 5 & $71.4 \%$ & \\
\hline \multirow[t]{3}{*}{ Cancellation of Training Schedules } & No its not & 31 & $68.9 \%$ & 14 & $31.1 \%$ & \multirow[b]{3}{*}{$19.249(0.000)$} \\
\hline & Yes its & 68 & $35.1 \%$ & 126 & $64.9 \%$ & \\
\hline & I do not know & 7 & $63.6 \%$ & 4 & $36.4 \%$ & \\
\hline \multirow[t]{3}{*}{ Loss of motivation teach again (in the long ran) } & No its not & 34 & $61.8 \%$ & 21 & $38.2 \%$ & \multirow[b]{3}{*}{$11.094(0.004)$} \\
\hline & Yes its & 70 & $37.2 \%$ & 118 & $62.8 \%$ & \\
\hline & I do not know & 2 & $28.6 \%$ & 5 & $71.4 \%$ & \\
\hline
\end{tabular}

Table 7 Test of Association Between Government Intervention Effectiveness to Cease the COVID-I9 and Its Positive Impact on the Respondents' Activities

\begin{tabular}{|c|c|c|c|c|c|c|}
\hline \multirow{2}{*}{$\begin{array}{l}\text { Positive Impact of Intervention Measures Taken by the } \\
\text { Government to Mitigate the Pandemic }\end{array}$} & \multirow{2}{*}{$\begin{array}{l}\text { Response } \\
\text { Categories }\end{array}$} & \multicolumn{2}{|c|}{ Not Effective } & \multicolumn{2}{|c|}{ Effective } & \multirow{2}{*}{$\begin{array}{l}\text { Chi-Square } \\
\text { (Sig.) }\end{array}$} \\
\hline & & Count & $\%$ & Count & $\%$ & \\
\hline Teachers are able to give Family care & $\begin{array}{l}\text { No I did not } \\
\text { Yes I do }\end{array}$ & $\begin{array}{l}26 \\
80\end{array}$ & $\begin{array}{l}70.3 \% \\
37.6 \%\end{array}$ & $\begin{array}{l}11 \\
133\end{array}$ & $\begin{array}{l}29.7 \% \\
62.4 \%\end{array}$ & $14.168(0.001)$ \\
\hline Have got time for watching movies & $\begin{array}{l}\text { No I did not } \\
\text { Yes I do } \\
\text { I do not know }\end{array}$ & $\begin{array}{l}27 \\
76 \\
3\end{array}$ & $\begin{array}{l}31.4 \% \\
47.8 \% \\
60.0 \%\end{array}$ & $\begin{array}{l}59 \\
83 \\
2\end{array}$ & $\begin{array}{l}68.6 \% \\
52.2 \% \\
40.0 \%\end{array}$ & $6.796(0.033)$ \\
\hline Have got time for doing physical activity & $\begin{array}{l}\text { No I did not } \\
\text { Yes I do }\end{array}$ & $\begin{array}{l}33 \\
73\end{array}$ & $\begin{array}{l}28.2 \% \\
54.9 \%\end{array}$ & $\begin{array}{l}84 \\
60\end{array}$ & $\begin{array}{l}71.8 \% \\
45.1 \%\end{array}$ & $18.473(0.000)$ \\
\hline
\end{tabular}

Based on the results displayed in Table 17, getting the flu vaccine is significant at the $1 \%$ level. The value of $\exp (\hat{\beta})=1.121$ implies that educators who have responded as getting flu vaccine is effective preventive measure of the disease were 1.121 times more likely to respond the intervention is effective as compared to those who said not and the value of $\exp (\hat{\beta})=4.124$ implies that educators who have responded as they did not know were 4.124 times more likely to respond the intervention is effective as compared to those who said not.
Similarly, respondent type of information mostly needed related to how to maintain one's mental health during the isolation is significant at the $1 \%$ level. The value of $\exp (\hat{\beta})=4.728$ implies that the odds of responding as the intervention is effective increases by a factor of 4.728 for those respondent educators who responded as they mostly needed about how to maintain one's mental health during the isolation as compared to those who did not mostly need information about how to maintain one's mental health during the isolation. 


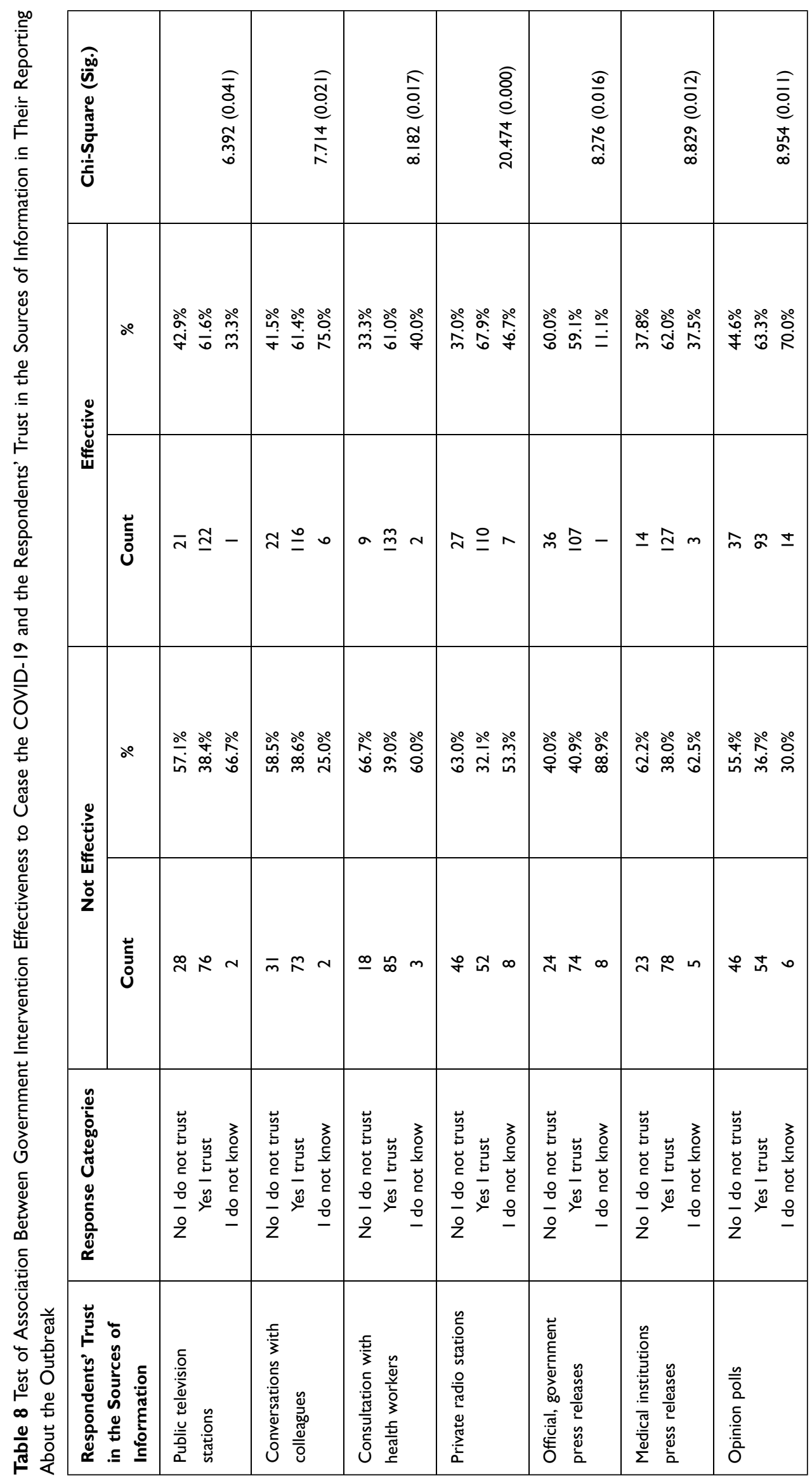


Table 9 Test of Association Between Government Intervention Effectiveness to Cease the COVID-19 and Types Information Respondents Mostly Need Related to

\begin{tabular}{|c|c|c|c|c|c|c|}
\hline \multirow{2}{*}{$\begin{array}{l}\text { Types Information Respondents Mostly Need } \\
\text { Related to }\end{array}$} & \multirow{2}{*}{$\begin{array}{l}\text { Response } \\
\text { Categories }\end{array}$} & \multicolumn{2}{|c|}{ Not Effective } & \multicolumn{2}{|c|}{ Effective } & \multirow{2}{*}{$\begin{array}{l}\text { Chi-Square } \\
\text { (Sig.) }\end{array}$} \\
\hline & & Count & $\%$ & Count & $\%$ & \\
\hline \multirow{2}{*}{$\begin{array}{l}\text { Personal stories from other people on how they } \\
\text { cope with the pandemic situation }\end{array}$} & No & 21 & $26.2 \%$ & 59 & $73.8 \%$ & \multirow{2}{*}{$12.564(0.000)$} \\
\hline & Yes & 85 & $50.0 \%$ & 85 & $50.0 \%$ & \\
\hline \multirow{2}{*}{$\begin{array}{l}\text { How they can take care of a person who belongs to } \\
\text { a risk group }\end{array}$} & No & 38 & $29.7 \%$ & 90 & $70.3 \%$ & \multirow{2}{*}{ I7.357 (0.000) } \\
\hline & Yes & 68 & $55.7 \%$ & 54 & $44.3 \%$ & \\
\hline \multirow{2}{*}{$\begin{array}{l}\text { How they can best take care of their children's } \\
\text { school education }\end{array}$} & No & 29 & $63.0 \%$ & 17 & $37.0 \%$ & \multirow{2}{*}{$9.837(0.002)$} \\
\hline & Yes & 77 & $37.7 \%$ & 127 & $62.3 \%$ & \\
\hline \multirow{2}{*}{$\begin{array}{l}\text { How the novel coronavirus is different from other } \\
\text { diseases such as flu }\end{array}$} & No & 36 & $35.0 \%$ & 67 & $65.0 \%$ & \multirow{2}{*}{$3.979(0.046)$} \\
\hline & Yes & 70 & $47.6 \%$ & 77 & $52.4 \%$ & \\
\hline \multirow{2}{*}{$\begin{array}{l}\text { How they will be impacted economically by the } \\
\text { pandemic }\end{array}$} & No & 15 & $19.0 \%$ & 64 & $81.0 \%$ & \multirow{2}{*}{$25.923(0.000)$} \\
\hline & Yes & 91 & $53.2 \%$ & 80 & $46.8 \%$ & \\
\hline \multirow{2}{*}{$\begin{array}{l}\text { How to maintain their mental health during the } \\
\text { isolation time }\end{array}$} & No & 44 & $33.8 \%$ & 86 & $66.2 \%$ & \multirow{2}{*}{$8.114(0.004)$} \\
\hline & Yes & 62 & $51.7 \%$ & 58 & $48.3 \%$ & \\
\hline
\end{tabular}

Table 10 Test of Association Between Government Intervention Effectiveness to Cease the COVID-19 and the Frequency of Respondent to Inform Themselves About the Novel Coronavirus per Day

\begin{tabular}{|c|c|c|c|c|c|c|c|}
\hline \multicolumn{2}{|l|}{ Indicator Variable } & \multirow[t]{2}{*}{$\begin{array}{l}\text { Response } \\
\text { Categories }\end{array}$} & \multicolumn{2}{|c|}{$\begin{array}{c}\text { Not } \\
\text { Effective }\end{array}$} & \multicolumn{2}{|c|}{ Effective } & \multirow[t]{2}{*}{$\begin{array}{l}\text { Chi-Square } \\
\text { (Sig.) }\end{array}$} \\
\hline & & & Count & $\%$ & Count & $\%$ & \\
\hline $\begin{array}{l}\text { Frequency of Information respondents inform to } \\
\text { themselves per day }\end{array}$ & $\begin{array}{c}\text { Never } \\
\text { Not Several times a day } \\
\text { Several times a day } \\
\text { Many Times a day }\end{array}$ & $\begin{array}{c}8 \\
8 \\
33 \\
15\end{array}$ & $\begin{array}{l}19.5 \% \\
53.3 \% \\
37.9 \% \\
62.5 \%\end{array}$ & $\begin{array}{c}33 \\
7 \\
54 \\
9\end{array}$ & $\begin{array}{l}80.5 \% \\
46.7 \% \\
62.1 \% \\
37.5 \%\end{array}$ & & $16.497(0.002)$ \\
\hline
\end{tabular}

From the results of logistic regression analysis, we can see that family care is a significant predictor of intervention effectiveness.

From the results, as an individual limitation in cooperating to cease the disease, we can see that respondents who responded not follow government preventive measures are 14.270 times more likely to rate the government intervention measures are effective as compared to those who responded as they did not follow government intervention measures at all. Similarly, respondents who responded others are 3.766 times more likely to rate the government intervention effectively as compared to those who responded as they did not follow government intervention measures at all, kept constant all other explanatory variables in the specified model.

\section{Discussion}

From the result of descriptive statistics analysis, $57.6 \%$ of the respondents were reported the intervention action applied by the government was effective to scrub COVID-19 in Dire Dawa City.

Based on the findings of bivariate analysis, out of indicator variables those have used in the survey; eighty-four of them were found to have a significant association with government intervention measure effectiveness in halting the spread of novel coronavirus, which are summarized and presented as follows: for various indicator variables: respondents' level of knowledge about the pandemic, respondents' susceptibility to be infected with the novel coronavirus, illness severity due to the disease if happen, knowledge how to protect from coronavirus, avoiding an infection with the novel coronavirus in the current situation, knowledge and 
Table II Test of Association Between Government Intervention Effectiveness to Cease the COVID-19 and Respondents Use of Sources of Information to Stay Informed About Novel Coronavirus

\begin{tabular}{|c|c|c|c|c|c|c|}
\hline \multirow{2}{*}{$\begin{array}{l}\text { Respondents Use of Sources of Information to Stay Informed } \\
\text { About Novel Coronavirus }\end{array}$} & \multirow{2}{*}{$\begin{array}{l}\text { Response } \\
\text { Categories }\end{array}$} & \multicolumn{2}{|c|}{ Not Effective } & \multicolumn{2}{|c|}{ Effective } & \multirow[t]{2}{*}{ Chi-Square (Sig.) } \\
\hline & & Count & $\%$ & Count & $\%$ & \\
\hline \multirow[t]{5}{*}{ Daily or weekly newspapers } & Never & 34 & $38.2 \%$ & 55 & $61.8 \%$ & \\
\hline & Rarely & 9 & $21.4 \%$ & 33 & $78.6 \%$ & \\
\hline & Sometimes & 37 & $56.1 \%$ & 29 & $43.9 \%$ & \\
\hline & Often & 18 & $45.0 \%$ & 22 & $55.0 \%$ & \\
\hline & Always & 8 & $61.5 \%$ & 5 & $38.5 \%$ & $15.309(0.004)$ \\
\hline \multirow[t]{5}{*}{ Conversations with family and friends } & Never & 2 & $50.0 \%$ & 2 & $50.0 \%$ & \\
\hline & Rarely & 18 & $50.0 \%$ & 18 & $50.0 \%$ & \\
\hline & Sometimes & 27 & $30.3 \%$ & 62 & $69.7 \%$ & \\
\hline & Often & 25 & $37.3 \%$ & 42 & $62.7 \%$ & \\
\hline & Always & 34 & $63.0 \%$ & 20 & $37.0 \%$ & $16.308(0.003)$ \\
\hline \multirow[t]{5}{*}{ Conversation with colleagues } & Never & 9 & $60.0 \%$ & 6 & $40.0 \%$ & \\
\hline & Rarely & 23 & $41.8 \%$ & 32 & $58.2 \%$ & \\
\hline & Sometimes & 32 & $34.0 \%$ & 62 & $66.0 \%$ & \\
\hline & Often & 16 & $30.8 \%$ & 36 & $69.2 \%$ & \\
\hline & Always & 26 & $76.5 \%$ & 8 & $23.5 \%$ & $23.639(0.000)$ \\
\hline \multirow[t]{5}{*}{ Private television stations } & Never & 8 & $42.1 \%$ & 11 & $57.9 \%$ & \\
\hline & Rarely & 6 & $22.2 \%$ & 21 & $77.8 \%$ & \\
\hline & Sometimes & 45 & $45.5 \%$ & 54 & $54.5 \%$ & \\
\hline & Often & 26 & $35.6 \%$ & 47 & $64.4 \%$ & \\
\hline & Always & 21 & $65.6 \%$ & 11 & $34.4 \%$ & $13.323(0.000)$ \\
\hline \multirow[t]{5}{*}{ Websites or online news pages } & Never & 13 & $100.0 \%$ & 0 & $0.0 \%$ & \\
\hline & Rarely & 16 & $18.4 \%$ & 71 & $81.6 \%$ & \\
\hline & Sometimes & 35 & $45.5 \%$ & 42 & $54.5 \%$ & \\
\hline & Often & 19 & $52.8 \%$ & 17 & $47.2 \%$ & \\
\hline & Always & 23 & $62.2 \%$ & 14 & $37.8 \%$ & $45.993(0.000)$ \\
\hline \multirow[t]{5}{*}{ Social media (eg Facebook, Twitter, YouTube, WhatsApp) } & Never & 6 & $75.0 \%$ & 2 & $25.0 \%$ & \\
\hline & Rarely & 6 & $37.5 \%$ & 10 & $62.5 \%$ & \\
\hline & Sometimes & 36 & $55.4 \%$ & 29 & $44.6 \%$ & \\
\hline & Often & 39 & $47.0 \%$ & 44 & $53.0 \%$ & \\
\hline & Always & 19 & $24.4 \%$ & 59 & $75.6 \%$ & $19.236(0.001)$ \\
\hline \multirow[t]{5}{*}{ Private radio stations } & Never & 40 & $43.0 \%$ & 53 & $57.0 \%$ & \\
\hline & Rarely & 25 & $50.0 \%$ & 25 & $50.0 \%$ & \\
\hline & Sometimes & 11 & $20.8 \%$ & 42 & $79.2 \%$ & \\
\hline & Often & 19 & $52.8 \%$ & 17 & $47.2 \%$ & \\
\hline & Always & 11 & $61.1 \%$ & 7 & $38.9 \%$ & $15.532(0.004)$ \\
\hline \multirow[t]{5}{*}{ Official, government press releases } & Never & 9 & $42.9 \%$ & 12 & $57.1 \%$ & \\
\hline & Rarely & 23 & $63.9 \%$ & 13 & $36.1 \%$ & \\
\hline & Sometimes & 19 & $28.8 \%$ & 47 & $71.2 \%$ & \\
\hline & Often & 33 & $37.9 \%$ & 54 & $62.1 \%$ & \\
\hline & Always & 22 & $55.0 \%$ & 18 & $45.0 \%$ & $15.128(0.004)$ \\
\hline \multirow[t]{5}{*}{ Medical institutions press releases } & Never & II & $57.9 \%$ & 8 & $42.1 \%$ & \\
\hline & Rarely & 18 & $56.2 \%$ & 14 & $43.8 \%$ & \\
\hline & Sometimes & 18 & $27.7 \%$ & 47 & $72.3 \%$ & \\
\hline & Often & 28 & $33.7 \%$ & 55 & $66.3 \%$ & \\
\hline & Always & 31 & $60.8 \%$ & 20 & $39.2 \%$ & $19.748(0.001)$ \\
\hline
\end{tabular}

(Continued) 
Table I I (Continued).

\begin{tabular}{|l|c|c|c|c|c|c|}
\hline Respondents Use of Sources of Information to Stay Informed & \multirow{2}{*}{$\begin{array}{c}\text { Response } \\
\text { About Novel Coronavirus }\end{array}$} & \multicolumn{2}{|c|}{ Not Effective } & \multicolumn{2}{|c|}{ Effective } & \multicolumn{2}{|c|}{ Chi-Square (Sig.) } \\
\cline { 3 - 6 } & Categories & Count & $\%$ & Count & $\%$ & \\
\hline Opinion polls & Never & 58 & $47.5 \%$ & 64 & $52.5 \%$ & \\
& Rarely & 15 & $24.2 \%$ & 47 & $75.8 \%$ & \\
& Sometimes & 9 & $39.1 \%$ & 14 & $60.9 \%$ & \\
& Often & 11 & $44.0 \%$ & 14 & $56.0 \%$ & \\
& Always & 13 & $72.2 \%$ & 5 & $27.8 \%$ & $16.417(0.003)$ \\
\hline Celebrities and social media influencers & Never & 17 & $53.1 \%$ & 15 & $46.9 \%$ & \\
& Rarely & 30 & $41.7 \%$ & 42 & $58.3 \%$ & \\
& Sometimes & 29 & $34.1 \%$ & 56 & $65.9 \%$ & \\
& Often & 16 & $39.0 \%$ & 25 & $61.0 \%$ & \\
& Always & 14 & $70.0 \%$ & 6 & $30.0 \%$ & $10.340(0.035)$ \\
\hline
\end{tabular}

self-assessed adherence to preventive measures, feeling of respondents about the closeness of COVID-19, newness of the outbreak, spread-ability of the pandemic, stressfulness of the disease, and frequency of respondent to inform themselves about the novel coronavirus per day.

For respondents' awareness about the symptoms of the novel coronavirus: fever, cough, shortness of breath, sore throat, headaches, fatigue, loss of taste and smell.

Prevention measure practice taken by the respondents to prevent infection from the novel coronavirus: hand washing for at least 20 seconds, refrain from touching one's body with unwashed hands, use of disinfectant/sanitizers to clean hands, physical distancing (keeping minimum 2 meters or 6 feet), and disinfecting surfaces as preventive measure taken by the respondent.

For effective actions applied for prevention the outbreak in the city: being home at the time of sick, herbal supplement, getting the flu vaccine, using antibiotics, using homeopathic remedies, self-isolation, disinfecting surfaces considered as effective preventive method by the respondent, and disinfecting the mobile phone.

For short-long term effects of government intervention: sufficiency of government intervention measures, individual effectiveness in using government the prevention measure, advantage of government intervention in scrubbing the disease, importance rate of the intervention, limitation of government intervention to cease the disease, limitation of the surrounding community in cooperating to cease the disease, individual limitation in cooperating to cease the disease, respondents' attitude towards the 14 days quarantine, and responses by surrounding community to help each other.
For the negative impact of government intervention on the respondents' activities: teachers are obligated to stay at home, unemployment, stress, unable to conduct professional activities, cancellation of training schedules, and loss of motivation teach again (in the long run).

For positive impact of government intervention on the respondents' activities: teachers are able to give family care, have time for watching movies, and have time for doing physical activity.

The respondents' trust in the sources of information in their reporting about the outbreak: public television stations, conversations with colleagues, consultation with health workers, private radio stations, official, government press releases, medical institutions press releases, and opinion polls.

For types information respondents mostly need related to: personal stories from other people on how they cope with the pandemic situation, how they can take care of a person who belongs to a risk group, how they can best take care of their children's school education, how the novel coronavirus is different from other diseases such as flu, how they will be impacted economically by the pandemic, and how to maintain their mental health during the isolation.

For respondents' use of sources of information to stay informed about novel coronavirus: daily or weekly newspapers, conversations with family and friends, conversation with colleagues, private television stations, websites or online news pages, social media (eg, Facebook, Twitter, YouTube, WhatsApp), private radio station, official, government press releases, medical institutions press releases, opinion polls, and celebrities and social media influencers. 
Table 12 Test of Association Between Government Intervention Effectiveness to Cease the COVID-19 and Trust (Perceptions) of Respondents in Institutions Those Inform Them About the Disease

\begin{tabular}{|c|c|c|c|c|c|c|}
\hline \multirow{2}{*}{$\begin{array}{l}\text { Trust (Perceptions) of Respondents in Institutions Those } \\
\text { Inform Them About the Disease }\end{array}$} & \multirow[t]{2}{*}{ Response Categories } & \multicolumn{2}{|c|}{ Not Effective } & \multicolumn{2}{|c|}{ Effective } & \multirow[t]{2}{*}{ Chi-Square (Sig.) } \\
\hline & & Count & $\%$ & Count & $\%$ & \\
\hline \multirow[t]{5}{*}{ Respondents Employer (if applicable) } & Very Low & 49 & $47.1 \%$ & 55 & $52.9 \%$ & \\
\hline & Low & 11 & $22.9 \%$ & 37 & $77.1 \%$ & \\
\hline & Neutral & 26 & $53.1 \%$ & 23 & $46.9 \%$ & \\
\hline & High & 16 & $39.0 \%$ & 25 & $61.0 \%$ & \\
\hline & Very High & 4 & $50.0 \%$ & 4 & $50.0 \%$ & $11.068(0.026)$ \\
\hline \multirow[t]{5}{*}{ Media } & Very Low & 10 & $21.3 \%$ & 37 & $78.7 \%$ & \\
\hline & Low & 14 & $58.3 \%$ & 10 & $41.7 \%$ & \\
\hline & Neutral & 20 & $44.4 \%$ & 25 & $55.6 \%$ & \\
\hline & High & 52 & $43.7 \%$ & 67 & $56.3 \%$ & \\
\hline & Very High & 10 & $66.7 \%$ & 5 & $33.3 \%$ & $14.858(0.005)$ \\
\hline \multirow[t]{5}{*}{ Other opinion leaders } & Very Low & 37 & $39.8 \%$ & 56 & $60.2 \%$ & \\
\hline & Low & 26 & $34.2 \%$ & 50 & $65.8 \%$ & \\
\hline & Neutral & 12 & $36.4 \%$ & 21 & $63.6 \%$ & \\
\hline & High & 27 & $67.5 \%$ & 13 & $32.5 \%$ & \\
\hline & Very High & 4 & $50.0 \%$ & 4 & $50.0 \%$ & $13.348(0.010)$ \\
\hline \multirow[t]{5}{*}{ Ministry of Health } & Very Low & 3 & $33.3 \%$ & 6 & $66.7 \%$ & \\
\hline & Low & 8 & $61.5 \%$ & 5 & $38.5 \%$ & \\
\hline & Neutral & 4 & $25.0 \%$ & 12 & $75.0 \%$ & \\
\hline & High & 54 & $69.2 \%$ & 24 & $30.8 \%$ & \\
\hline & Very High & 37 & $27.6 \%$ & 97 & $72.4 \%$ & $39.227(0.000)$ \\
\hline \multirow[t]{5}{*}{ Medical professional associations } & Very Low & 6 & $50.0 \%$ & 6 & $50.0 \%$ & \\
\hline & Low & 14 & $35.9 \%$ & 25 & $64.1 \%$ & \\
\hline & Neutral & 34 & $32.7 \%$ & 70 & $67.3 \%$ & \\
\hline & High & 41 & $56.2 \%$ & 32 & $43.8 \%$ & \\
\hline & Very High & 11 & $50.0 \%$ & 11 & $50.0 \%$ & $11.155(0.025)$ \\
\hline \multirow[t]{5}{*}{ Schools } & Very Low & 15 & $39.5 \%$ & 23 & $60.5 \%$ & \\
\hline & Low & 27 & $30.3 \%$ & 62 & $69.7 \%$ & \\
\hline & Neutral & 26 & $51.0 \%$ & 25 & $49.0 \%$ & \\
\hline & High & 29 & $49.2 \%$ & 30 & $50.8 \%$ & \\
\hline & Very High & 9 & $69.2 \%$ & 4 & $30.8 \%$ & $11.907(0.018)$ \\
\hline \multirow[t]{5}{*}{ Kindergartens } & Very Low & 40 & $38.5 \%$ & 64 & $61.5 \%$ & \\
\hline & Low & 17 & $30.4 \%$ & 39 & $69.6 \%$ & \\
\hline & Neutral & 13 & $40.6 \%$ & 19 & $59.4 \%$ & \\
\hline & High & 30 & $68.2 \%$ & 14 & $31.8 \%$ & \\
\hline & Very High & 6 & $42.9 \%$ & 8 & $57.1 \%$ & $16.004(0.003)$ \\
\hline \multirow[t]{5}{*}{ Public transportation companies } & Very Low & 11 & $24.4 \%$ & 34 & $75.6 \%$ & \\
\hline & Low & 46 & $46.0 \%$ & 54 & $54.0 \%$ & \\
\hline & Neutral & 15 & $50.0 \%$ & 15 & $50.0 \%$ & \\
\hline & High & 25 & $54.3 \%$ & 21 & $45.7 \%$ & \\
\hline & Very High & 9 & $31.0 \%$ & 20 & $69.0 \%$ & $11.403(0.022)$ \\
\hline \multirow[t]{5}{*}{ Police } & Very Low & 5 & $14.3 \%$ & 30 & $85.7 \%$ & \\
\hline & Low & 14 & $32.6 \%$ & 29 & $67.4 \%$ & \\
\hline & Neutral & 41 & $40.6 \%$ & 60 & $59.4 \%$ & \\
\hline & High & 28 & $62.2 \%$ & 17 & $37.8 \%$ & \\
\hline & Very High & 18 & $69.2 \%$ & 8 & $30.8 \%$ & $28.072(0.000)$ \\
\hline
\end{tabular}

(Continued) 
Table 12 (Continued).

\begin{tabular}{|c|c|c|c|c|c|c|}
\hline \multirow{2}{*}{$\begin{array}{l}\text { Trust (Perceptions) of Respondents in Institutions Those } \\
\text { Inform Them About the Disease }\end{array}$} & \multirow[t]{2}{*}{ Response Categories } & \multicolumn{2}{|c|}{ Not Effective } & \multicolumn{2}{|c|}{ Effective } & \multirow[t]{2}{*}{ Chi-Square (Sig.) } \\
\hline & & Count & $\%$ & Count & $\%$ & \\
\hline \multirow[t]{5}{*}{ Army } & Very Low & 14 & $63.6 \%$ & 8 & $36.4 \%$ & \\
\hline & Low & 37 & $37.4 \%$ & 62 & $62.6 \%$ & \\
\hline & Neutral & 10 & $31.2 \%$ & 22 & $68.8 \%$ & \\
\hline & High & 35 & $66.0 \%$ & 18 & $34.0 \%$ & \\
\hline & Very High & 10 & $22.7 \%$ & 34 & $77.3 \%$ & $25.814(0.000)$ \\
\hline \multirow[t]{5}{*}{ The President/Prime Minister } & Very Low & 7 & $58.3 \%$ & 5 & $41.7 \%$ & \\
\hline & Low & 4 & $44.4 \%$ & 5 & $55.6 \%$ & \\
\hline & Neutral & 26 & $59.1 \%$ & 18 & $40.9 \%$ & \\
\hline & High & 46 & $41.8 \%$ & 64 & $58.2 \%$ & \\
\hline & Very High & 23 & $30.7 \%$ & 52 & $69.3 \%$ & $10.525(0.032)$ \\
\hline
\end{tabular}

Table I 3 Summary Statistics of the Likelihood Ratio Test

\begin{tabular}{|l|l|l|l|l|}
\hline \multicolumn{2}{|l|}{$\mathbf{2}$ Log Likelihood } & \multicolumn{2}{l|}{ Likelihood Ratio Tests. } \\
\hline Null Model (Intercept Only) & Final Model & Chi-Square & D.F. & Sig. \\
\hline 340.775 & 159.485 & 181.290 & 14 & 0.000 \\
\hline
\end{tabular}

Table 14 Model Summary

\begin{tabular}{|l|l|l|}
\hline $\begin{array}{l}-2 \text { Log } \\
\text { Likelihood }\end{array}$ & $\begin{array}{l}\text { Cox \& Snell R } \\
\text { Square }\end{array}$ & $\begin{array}{l}\text { Nagelkerke R } \\
\text { Square }\end{array}$ \\
\hline 181.290 & 0.472 & 0.634 \\
\hline
\end{tabular}

Table 15 Hosmer and Lemeshow Test

\begin{tabular}{|l|l|l|}
\hline Chi-square & D.F. & Sig. \\
\hline 12.701 & 8 & 0.123 \\
\hline
\end{tabular}

For trust (perceptions) of respondents in institutions, those who inform them about the disease: respondents' employer (if applicable), media, other opinion leaders,
Ministry of Health, medical professional associations, schools, kindergartens, public transportation companies, police, army, and the president/prime minister.

In classical approach of binary logistic regression model only nine predictor variables were significant: refrain from touching one's body with unwashed hands, disinfecting surfaces, fatigue (tiredness), getting the flu vaccine, an individual limitation in cooperating to cease the disease, how to maintain one's mental health during the isolation, hand washing for at least 20 seconds, family care, and self-isolation (see Table 17).

Our study agrees with recent empirical studies on Humanitarian Impact, established multi-sectorial coordination meetings disrupted ${ }^{6}$ and with studies carried out in

Table 16 Classification Table for the Logistic Regression

\begin{tabular}{|l|l|l|l|l|}
\hline \multirow{2}{*}{ Observed } & \multicolumn{3}{|l|}{ Predicted } \\
\cline { 3 - 5 } & & Government Intervention Effectiveness & Percentage \\
\cline { 3 - 5 } & Not Effective & 95 & 11 & Effective \\
\hline Government intervention effectiveness & Not effective & 22 & 122 & 89.6 \\
\hline Overall Percentage & Effective & & 84.7 & 86.8 \\
\hline
\end{tabular}




\begin{tabular}{|c|c|c|c|c|c|c|c|c|c|c|c|c|c|c|c|c|c|c|c|c|}
\hline \multirow{2}{*}{ 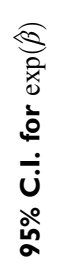 } & ڤั & $\begin{array}{l}\bar{\sigma} \\
\text { in } \\
\text { in }\end{array}$ & 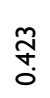 & & $\begin{array}{c}\stackrel{ \pm}{0} \\
0 \\
0\end{array}$ & $\begin{array}{l}\text { \& } \\
\text { o. }\end{array}$ & & 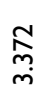 & $\begin{array}{l}\stackrel{\alpha}{\alpha} \\
\text { İ }\end{array}$ & & $\begin{array}{c}\overline{0} \\
\stackrel{0}{0}\end{array}$ & $\frac{\hat{n}}{\underline{\underline{O}}}$ & 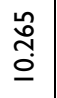 & 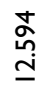 & 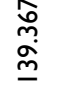 & $\frac{\stackrel{\circ}{m}}{\stackrel{\sim}{N}}$ & & $\underset{\bar{\sigma}}{\bar{\sigma}}$ & $\frac{\hat{\lambda}}{0}$ & \\
\hline & נִ & 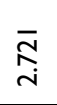 & $\begin{array}{l}\stackrel{o}{0}_{0} \\
\text { O. }\end{array}$ & & 뭉 & 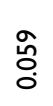 & & 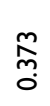 & 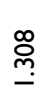 & & $\underset{\substack{m \\
m}}{ \pm}$ & 命 & ̊̊ & 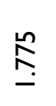 & 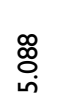 & 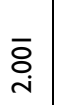 & & $\overline{\bar{o}}$ & 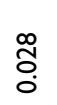 & \\
\hline $\begin{array}{l}\widehat{s} \\
\text { क्षे }\end{array}$ & & 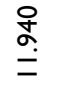 & $\frac{n}{0}$ & & ठ̊े & 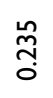 & & $\stackrel{\bar{I}}{\underline{\underline{Y}}}$ & 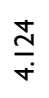 & & $\begin{array}{l}\stackrel{P}{\text { I }} \\
\text { İ }\end{array}$ & 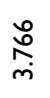 & $\begin{array}{l}\tilde{\sigma} \\
\stackrel{\sim}{+}\end{array}$ & $\underset{\underset{\sim}{\stackrel{\sim}{N}}}{\stackrel{\infty}{\sim}}$ & $\begin{array}{l}\stackrel{\infty}{\omega} \\
\stackrel{\omega}{\oplus} \\
\end{array}$ & 苞 & & $\frac{\varnothing}{0}$ & $\frac{\bar{\sigma}}{0}$ & ồ \\
\hline$\dot{0}$ & & $\overline{8}$ & ষ̊ㅇ. & oे & ర్ & $\begin{array}{l}\bar{\sigma} \\
0\end{array}$ & ¿̊. & 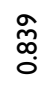 & 응 & ڤ్ర & 웅 & 。े & $\frac{\hat{y}}{0}$ & ઠ̊ & ঃ̊ & ర్ & $\begin{array}{l}\text { 合 } \\
\text { O. }\end{array}$ & $\begin{array}{l}+ \\
\text { Ho. } \\
\text { Oे }\end{array}$ & $\frac{\infty}{0}$ & 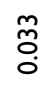 \\
\hline
\end{tabular}

崩

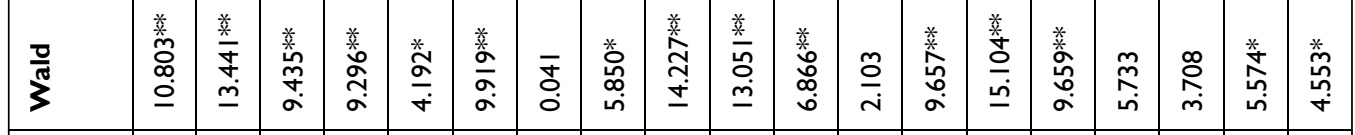

\begin{tabular}{|c|c|c|c|c|c|c|c|c|c|c|c|c|c|}
\hline $\mid \begin{array}{c}n \\
\vdots \\
0 \\
0\end{array}$ & & 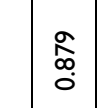 & $\begin{array}{l}\hat{a} \\
0 \\
0\end{array}$ & 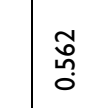 & 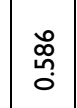 & 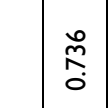 & \begin{tabular}{|l} 
\\
o. \\
o
\end{tabular} & $\begin{array}{l}\text { 怘 } \\
\stackrel{0}{0}\end{array}$ & & & & $\stackrel{\leftrightarrow \stackrel{\leftrightarrow}{=}}{=}$ & $\underset{\varpi}{\tilde{\Xi}}$ \\
\hline$\stackrel{n}{i}$ & & $\hat{i}$ & & $\overline{0}$ & $\underline{I}$ & 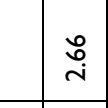 & 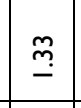 & & 色 & & & $\tilde{\tau}$ & \\
\hline
\end{tabular}

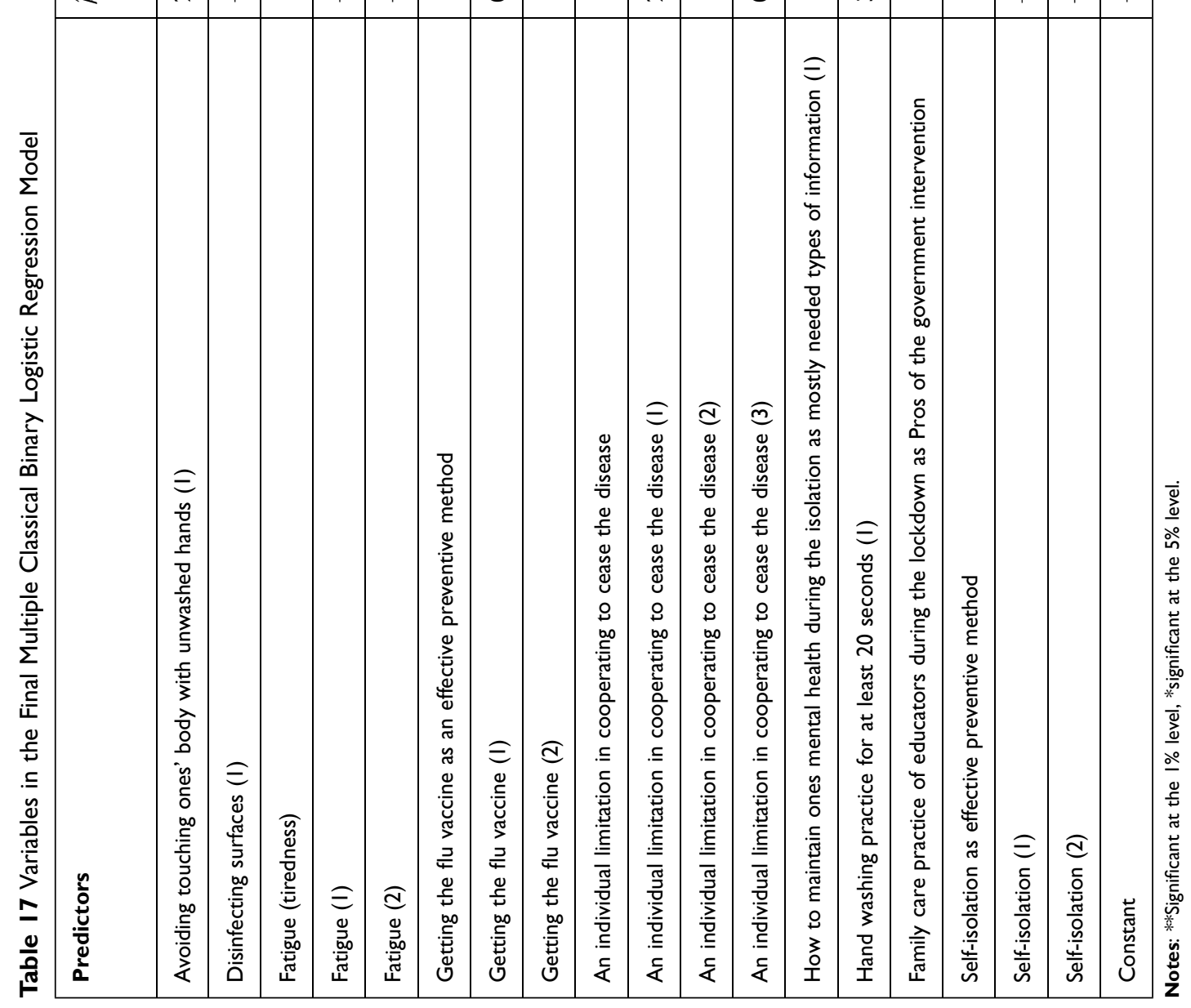




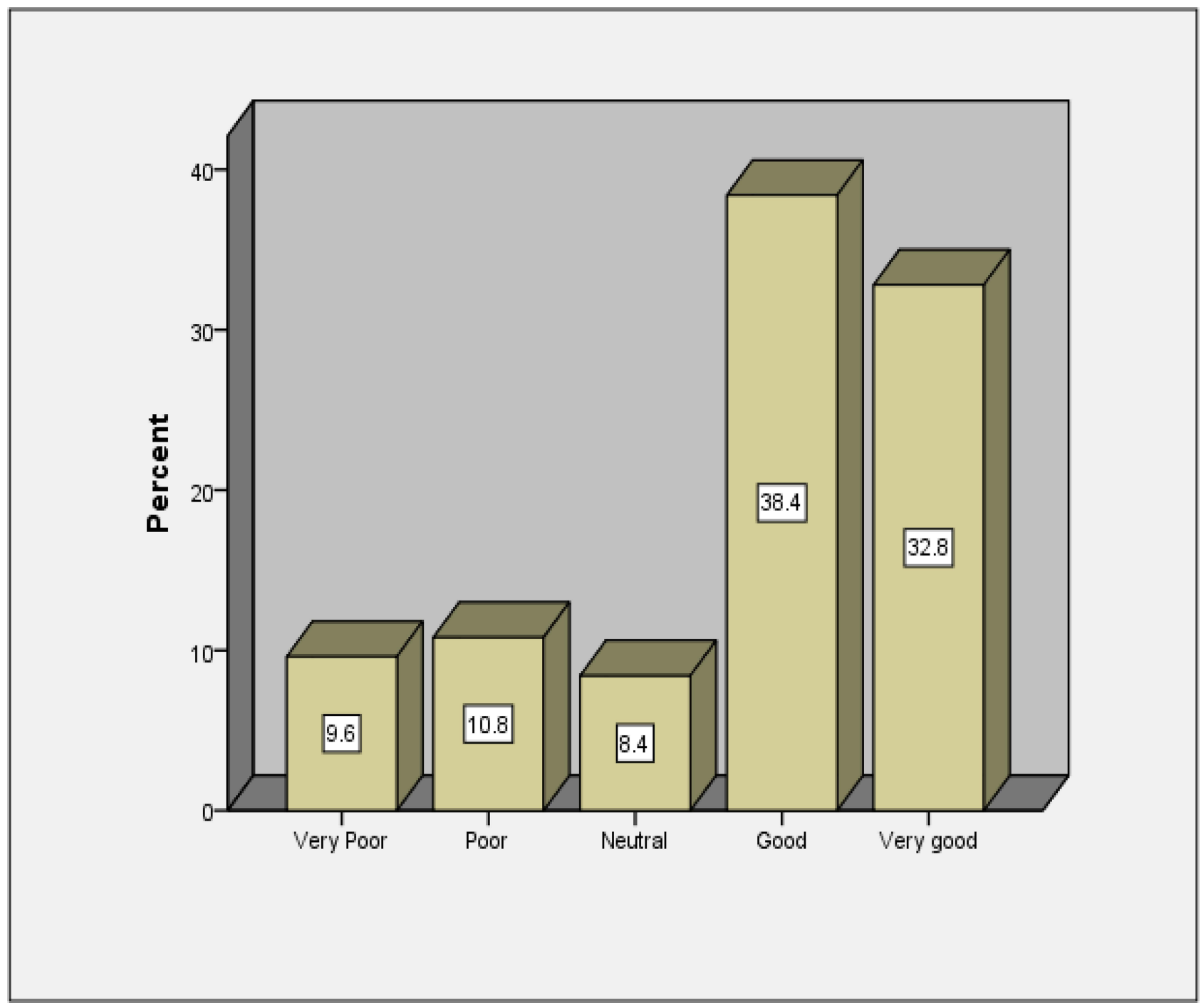

Figure I Bar chart, the respondent educators' level of knowledge about the pandemic in Dire Dawa City in 2020. From Figure I, one can see that majority of the respondents have good knowledge about the pandemic in Dire Dawa City at the time of the study.

WHO region countries the delay in initiating travel restrictions, social distancing measures or lockdown and violations of measures lead to rapid the increase of cases and deaths in Iran. ${ }^{18}$

The following eight lessons were taken as important measures in reducing and controlling the disease: ${ }^{19} 1$. acting early: as the pandemic is starting as small outbreaks but intensifying exponentially it is necessary to initiate action when the threat appears small. Decisions on reporting, travel restrictions, ban on mass/religious gatherings should be taken early, eg, KSA, Germany. ${ }^{19} 2$. Epidemiological investigations, contact tracing and containment measures: countries with extensive testing and contact tracing like China, Singapore, South Korea and Germany showed better outcomes than countries with limited testing like Italy. ${ }^{19}$ 3. Hospital preparedness: enhancing testing capacity, manpower training and increase in hospital resources like isolation wards, ICU and ventilators as done by countries like Germany, which have a low CFR, Singapore and China. ${ }^{19} 4$. Monitoring and reporting: essential to have a data documentation and dissemination process to plan the resources wisely and provide right information to people, eg, Singapore, China. ${ }^{19}$ 5. Low-cost innovations in patient testing and treatment, eg, Sri Lanka. ${ }^{19}$ 6. Safety of healthcare staff: not testing the healthcare staff on priority and shortage of PPE led to nosocomial infections and deaths among doctors as in Italy. ${ }^{19}$ 7. Stringent social distancing measures: total lockdown has better outcomes than phase-wise lockdown as observed in KSA in comparison with Iran. ${ }^{19}$ 8. A 


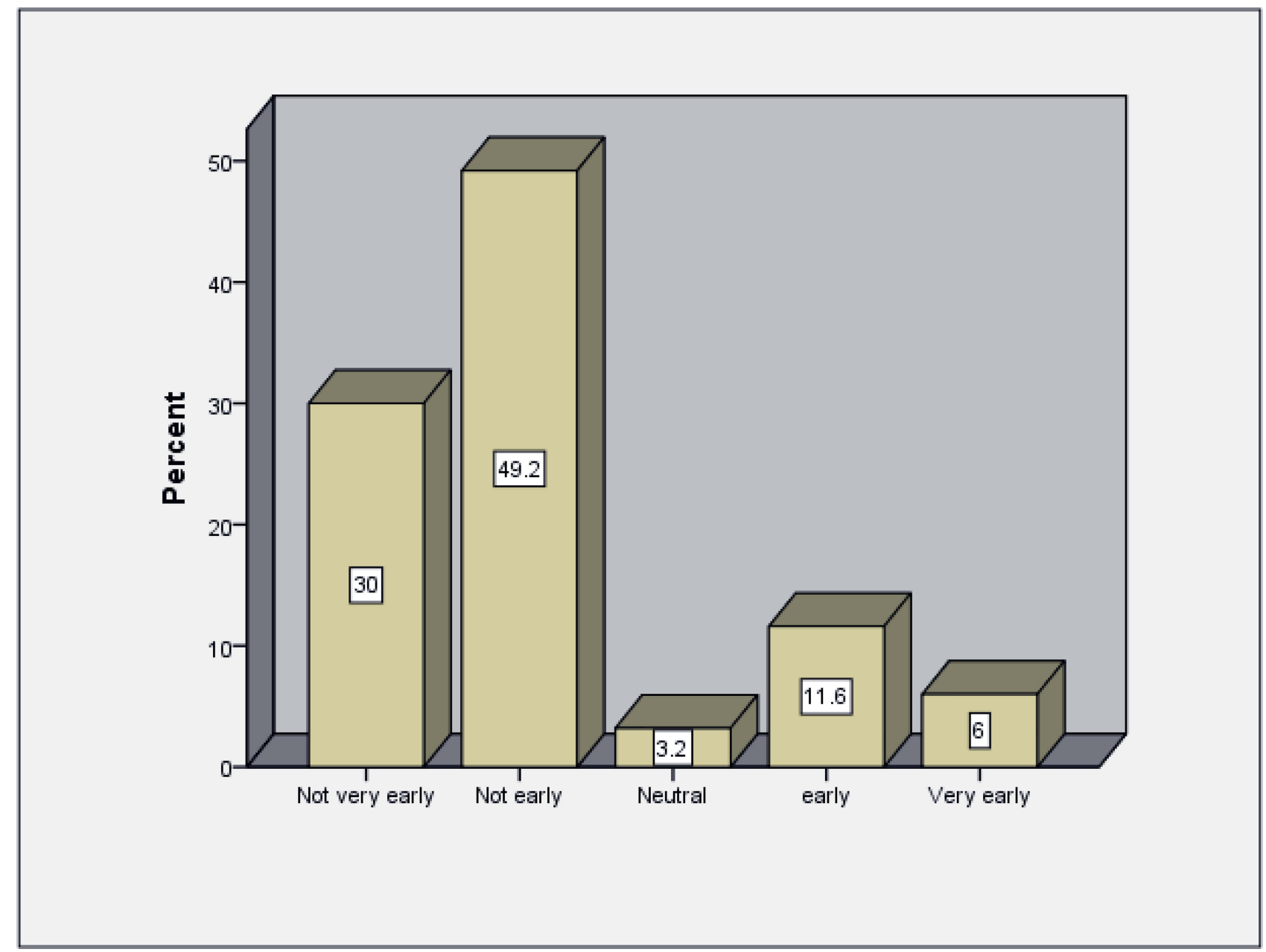

Figure 2 The rating of the timing of government intervention measures to scrub the disease in Dire Dawa City. From Figure 2 , one can visualize that $49.2 \%$ of the respondent educators rate the government's intervention measures timing was not early in Dire Dawa City.

prior experience of dealing with pandemics enables better preparedness and outcomes, eg, Singapore and KSA. ${ }^{19}$

Additionally, a study done in Italy by Giordano et $\mathrm{al}^{20}$ demonstrated that restrictive social-distancing measures will need to be combined with widespread testing and contact tracing to end the ongoing COVID-19 pandemic ${ }^{20}$ which is somehow in accordance with our study findings.

As another study done by Sweden ECDC ${ }^{21}$ implied that the preexisting number of hospital beds/1000 population in Germany was 8.3 when compared to 3.4 in Italy. ${ }^{21}$

Additionally, our study finding, among the types of information respondents need mostly related to, how to maintain one's mental health during the isolation time had an effect on the government intervention effectiveness, which can be taken in line with the results of the study conducted by Alvarez-Risco et $\mathrm{al}^{11}$ showed that Peru's healthcare workers' anxiety and mental distress decreased as the distance from the epicenter increases, corroborating the ripple effect and disconfirming the typhoon eye theory. ${ }^{11}$ A lower education level increased the anxiety levels, whereas age and gender did not affect the anxiety and distress levels. ${ }^{11}$ Alvarez-Risco et $\mathrm{al}^{11}$ have reported that their results can help guide mental health service providers toward vulnerable groups of healthcare workers that are closer to Lima; the COVID-19 epicenter in Peru. ${ }^{11}$

Similarly, anxiety of the educators was associated with government effectiveness in our study. Thus, our finding was in accordance with the study done by Alvarez-Risco et al. ${ }^{10}$

Further, the study made by Alvarez-Risco et $\mathrm{al}^{12}$ on the COVID-19 pandemic created an opportunity to expand telemedicine services. Alvarez-Risco et $\mathrm{al}^{12}$ foresee that telemedicine in Peru could help fortify disease prevention programs, monitor chronic disease patients, and combat malnutrition in vulnerable populations, such as pregnant women and children under 5 years old. Peru was forced into telemedicine due to the pandemic, and the government is working to improve Internet coverage. ${ }^{12}$ This also 


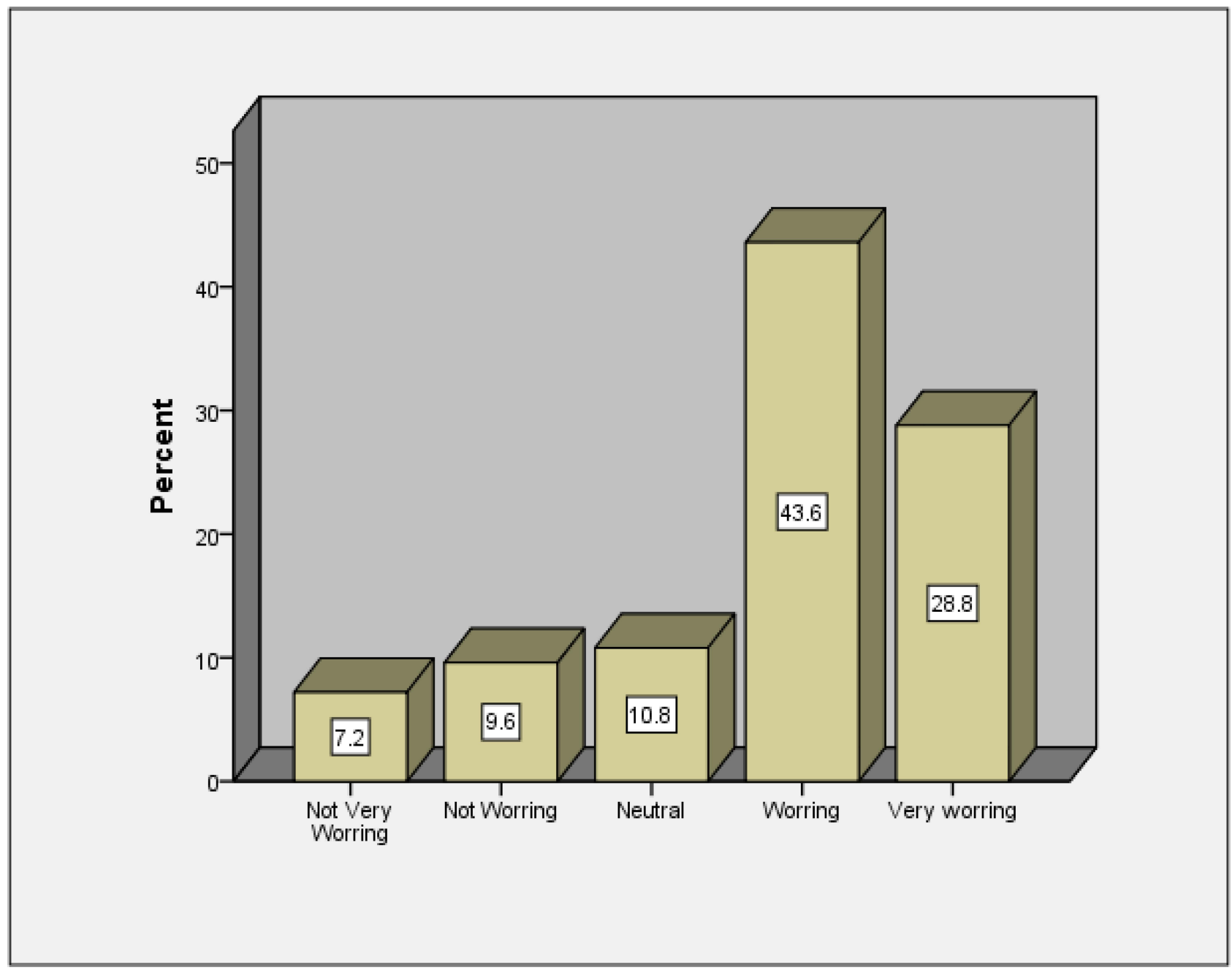

Figure 3 Bar chart shows the respondents, level of worry or feeling level about COVID-19 in Dire Dawa City. From Figure 3, one can visualize that 43.6\% of the respondent educators' rate they felt worrying about the pandemic in Dire Dawa City.

resembles our study finding since postgraduate classes were ran via online platform, and course materials were uploaded online for the undergraduate university students where the government was increased the access of the Internet to the students and to the teachers. Where the difference in telemedicine and online education services is considered.

Another study done by Alvarez-Risco et al $^{14}$ taking evidence from four countries: Colombia, Ecuador, Mexico, and Peru implied that COVID-19 has changed the world, ${ }^{14}$ in creating the need for new actions from society, including universities and companies $^{14}$ which agrees with our study.

A study done by Yáñez et $\mathrm{al}^{15}$ implied that self-medication affects both negatively and positively the health of people, which has become evident during the COVID-19 pandemic. $^{15}$ Yáñez et $\mathrm{al}^{15}$ reported that there were significant percentages of self-medication, including drugs without sufficient scientific evidence, age, region where one lived and job status was variables associated with self-medication frequency.

Finally, Yáñez et $\mathrm{al}^{15}$ suggested that a continuous awareness and sensitization about the risks of self-medication are warranted which have more similar finding with our study in terms of respondents' perception to the symptoms, preventive methods, need of awareness creation and effective preventive methods of the pandemic.

where it differs in terms of demographic variables since demographic variables were not included in our questionnaires adopted from WHO standard questionnaires.

Similarly, the study performed by Yan et $\mathrm{al}^{16}$ signaled that the COVID-19 outbreak has highlighted the need to target infodemics that can be as detrimental as an actual 
epidemic. It will be a multifactorial fight because they will need to increase health literacy in the population, establish a stronger presence of national health agencies in social media, develop better detection tools, and enable action by governments, as Peru has implemented. This finding is also similar to ours because knowledge and perceptions of the respondents were significantly associated with government intervention measure effectiveness.

Further, as study done by Alvarez-Risco et al $^{17}$ implied Godlee appraises the UK government's response to COVID-19. On 18 May the Peruvian government started allowing supervised walks for people under 14 years old. Alvarez-Risco et $\mathrm{al}^{17}$ have previously expressed their concern for this measure, because it could lead to a rise in cases in children, who typically exhibit milder symptoms. Alvarez-Risco et $\mathrm{al}^{17}$ reported that there must be cautious in Peru, where there is a precarious health system, cases keep increasing in small children, paediatric hospitals are saturated with adult patients, and public policies are not necessarily following the global epidemiological alerts. This finding is in agreement with our study finding in terms of the need of cautious in Dire Dawa City too at the time of the study.

A study by Yan et al $^{16}$ signaled that the hospitality industry worldwide is suffering under the COVID-19 pandemic which is in parallel with our study finding that education institutes were suffering too under the pandemic in the Dire Dawa City.

On the other hand, a paper done by $\mathrm{UNOCHA}^{6}$ showed that

the impacts of education development, conceptual development, and country supports on the entrepreneur's ability to carry out green entrepreneurship were positive. ${ }^{6}$ The research findings also may be helpful for the governments in establishing new norms to promote entrepreneurship which is in line with our study that government can use new strategy to alleviate the pandemic.

\section{Conclusion}

Based on descriptive analysis of indicator $57.6 \%$ of the study participants reported as the government was effective in halting the pandemic in the city. On the other side, from bivariate analysis result, eighty-four indicator variables have a significant association with government's intervention effectiveness in halting the pandemic.

On the bases classical binary logistic regression analysis nine predictors significantly related with the government's intervention effectiveness in halting the pandemic in the study area: refrain from touching one's body with unwashed hands, disinfecting surfaces, fatigue (tiredness), getting the flu vaccine, individual limitation in cooperating to cease the disease, how to maintain one's mental health during the isolation, hand washing practice of respondents' for at least 20 seconds, respondents got time for family care during lockdown, and self-isolation were factors most probable affects government intervention effectiveness as shown in the discussion part of the document. We recommend that every concerned body has to give a considerable attention to prevention method of the disease in the study area.

Dire Dawa City Administration and the concerned body have to give the appropriate attention to the awareness of teachers about symptoms of the pandemic; to obtain an expected change.

Similarly, respondents' individual limitation in cooperating with government intervention measures to cease the disease has an important impact on the government intervention effectiveness. Therefore, it is better to improve the cooperating habit of the educators to the preventive measures of novel coronavirus in Dire Dawa City since individual has Lion's share in mitigating the spread of the outbreak.

Additionally, among the types of information respondents need mostly related to, how to maintain one's mental health during the isolation time had an effect on the government intervention effectiveness. Thus, appropriate and timely measures need to be taken by the Ministry of Health and other concerned bodies in providing advices and counseling regarding types of information respondents need mostly related about during the isolation time period.

Eventually, regarding the advantage of the outbreak the following indicators were significant: respondents were able to get time for reading, respondents were able to get chance of Family care practice, respondents were able to get chance of watching movies, and respondents were able to get involved in physical exercise activates were among the importance brought by the pandemic to the educators due to the lockdown intervention actions applied in the city.

On the contrary, the following indicators have significant negative impact on educational activities of respondents: teachers are obligated to stay at home, fear of unemployment, stress, unable to conduct professional activities, cancellation of training, and loss of motivation.

Thus, the concerned bodies in the city have to work together to alleviate such problems and to have a well and 
productive teacher by considering the intensity of the negative impacts of the pandemic in the city since it has both short- and long-term negative impacts on respondents' success. Generally, the cumulative success of the study participants can be considered as the government intervention success in study area.

\section{Abbreviations}

COVID-19, Coronavirus Disease 2019; JHU, Johns Hopkins University; MERS, Middle East Respiratory Syndrome; SARS, Severe Acute Respiratory Syndrome; UNOCHA, United Nations Office for the Coordination of Humanitarian Affairs; WHO, World Health Organization; WB, World Bank; and AGDH, Australian Government Department of Health.

\section{Acknowledgments}

The authors would like to thank Dire Dawa University: Department of Statistics, College of Natural and Computational Sciences, College of Social Sciences and Humanities, College of Medicine and Health Sciences, Research Affairs Directorate, Community Service and Research Affairs Vice President.

Additionally, we would like to forward our appreciation to Dawa Administration Health Bureau, Dire Dawa Administration Education Bureau, School Principals, School Coordinators, and School owners for their warm welcoming and support during data collection stage.

Finally, we are highly grateful for all participants, enumerators and data feeders.

\section{Author Contributions}

All authors participated in data analysis, preparing, reconsidering, and finalizing the article, gave final approval of the version to be published, agreed to the submitted journal, and agreed to be fully accountable for all aspects of the work.

\section{Disclosure}

The authors declare that they have no conflicts of interest in this study.

\section{References}

1. Australian Government Department of Health.COVID-19 - Frequently asked questions; 2020. Available from: https://www.bluecross.com.au/ $\mathrm{mvc} / \mathrm{k} 12$ webapi/media/pdf/covid-19/coronavirus-covid-19-frequentlyasked-questions.pdf. Accessed September 15, 2021.

2. WHO. Global situation daily report; 2021. Available from: https:// www.who.int/. Accessed September 3, 2021.
3. DDA. Dire-Dawa-administration-health-bureau daily COVID-19 situational report; 2021. Available from: https://www.facebook.com/ . Accessed September 3, 2021.

4. JHU. Daily report of global coronavirus pandemic prevalence; 2020. Available from: https://coronavirus.jhu.edu/. Accessed September 3, 2021.

5. Liya T. Ethiopian ministry of health novel coronavirus daily report; 2020. Available from: https://www.moh.gov.et/ejcc/index.php/en. Accessed September 3, 2021.

6. UNOCHA. ETHIOPIA: COVID-19 humanitarian impact situation update No. 01; 2020. Available from: https://www.humanitarianresponse.info/en/ operations/ethiopia/covid-19. Accessed September 3, 2021.

7. Zhang SX, Chen J, Jahanshahi AA, et al. Succumbing to the COVID19 pandemic-healthcare workers not satisfied and intend to leave their jobs. Int J Ment Health Addict. 2021:1-10. doi:10.1007/ s11469-020-00418-6

8. Zhang SX, Sun S, Jahanshahi AA, et al. Developing and testing a measure of COVID-19 organizational support of healthcare workers - results from Peru, Ecuador, and Bolivia. Psychiatry Res. 2020;291:113174. doi:10.1016/j.psychres.2020.113174

9. Yáñez JA, Jahanshahi AA, Alvarez-Risco A, et al. Anxiety, distress, and turnover intention of healthcare workers in Peru by their distance to the epicenter during the COVID-19 crisis. Am J Trop Med Hyg. 2020;103(4):1614. doi:10.4269/ajtmh.20-0800

10. Alvarez-Risco A, Del-Aguila-Arcentales S, Yáñez JA. Perspective piece telemedicine in Peru as a result of the COVID-19 pandemic: perspective from a country with limited internet access. Am J Trop Med Hyg. 2021;105(1):6-11. doi:10.4269/ajtmh.21-0255

11. Alvarez-Risco A, Estrada-Merino A, de Las Mercedes Andersonseminario $\mathrm{M}$, et al. Multitasking behavior in online classrooms and academic performance: case of university students in Ecuador during COVID-19 outbreak. Interact Technol Smart Educ. 2020. Available from: https://www.emerald.com/insight/publication/issn/1741-5659. Accessed September 3, 2021.

12. Alvarez-Risco A, Del-Aguila-Arcentales S, Rosen MA, et al. Expectations and interests of university students in COVID-19 times about sustainable development goals: evidence from Colombia, Ecuador, Mexico, and Peru. Sustainability. 2021;13 (6):3306. doi:10.3390/su13063306

13. Aleidi S, Issa A, Bustanji H, Khalil M, Bustanji Y. Self-medication practices during the COVID-19 pandemic among the adult population in Peru: a cross-sectional survey. Saudi Pharm J. 2015;23(3):250256. doi:10.1016/j.jsps825

14. Alvarez-Risco A, Mejia CR, Delgado-Zegarra J, et al. The Peru approach against the COVID-19 Infodemic: insights and strategies. Am J Trop Med Hyg. 2020;103(2):583-586. doi:10.4269/ajtmh.200536

15. Yáñez JA, Alvarez-Risco A, Delgado-Zegarra J. Covid-19 in Peru: from supervised walks for children to the first case of Kawasaki-like syndrome. BMJ. 2020;369. doi:10.1136/bmj.m2418

16. Yan J, Kim S, Zhang SX, et al. Hospitality workers' COVID-19 risk perception and depression: a contingent model based on transactional theory of stress model. Int J Hosp Manag. 2021;95:102935. doi:10.1016/j.ijhm.2021.102935

17. Alvarez-Risco A, Mlodzianowska S, García-Ibarra V, et al. Factors affecting green entrepreneurship intentions in Business University Students in COVID-19 pandemic times: case of Ecuador. Sustainability. 2021;13(11):6447. doi:10.3390/ su13116447

18. WHO. Coronavirus disease situation reports; 2020. Available from: https://www.who.int/emergencies/diseases/novel-coronavirus-2019/ situation-reports. Accessed September 3, 2021.

19. Davalgi S, Undi M, Annadani R, et al. Comparison of measures adopted to combat COVID 19 pandemic by different countries in WHO regions. Indian J Community Health. 2020;32:288-299. 
20. Giordano G, Blanchini F, Bruno R, et al. Modeling the COVID19 epidemic and implementation of population-wide interventions in Italy. Nat Med. 2020;26(6). doi:10.1038/s41591-0200883-7
21. Sweden ECDC. Updated rapid risk assessment from ECDC on the novel Coronavirus disease 2019 (COVID-19) pandemic: increased transmission in the EU/EEA and the UK, Stockholm. Eurosurveillance. 2020;25 (10):2003121. doi:10.2807/1560-7917.ES.2020.25.12.2003261

\section{Publish your work in this journal}

The Journal of Multidisciplinary Healthcare is an international, peerreviewed open-access journal that aims to represent and publish research in healthcare areas delivered by practitioners of different disciplines. This includes studies and reviews conducted by multidisciplinary teams as well as research which evaluates the results or conduct of such teams or healthcare processes in general. The journal covers a very wide range of areas and welcomes submissions from practitioners at all levels, from all over the world. The manuscript management system is completely online and includes a very quick and fair peer-review system. Visit http://www.dovepress.com/testimonials. php to read real quotes from published authors. 